San Jose State University

SJSU ScholarWorks

Master's Projects

Master's Theses and Graduate Research

Spring 5-2020

\title{
Equity-Based Resource and Service Allocation for the City of San Josés Department of Parks, Recreation and Neighborhood Services
}

Patrick Córdova

San Jose State University

Follow this and additional works at: https://scholarworks.sjsu.edu/etd_projects

Part of the Policy Design, Analysis, and Evaluation Commons, Public Administration Commons, and the Recreation, Parks and Tourism Administration Commons

\section{Recommended Citation}

Córdova, Patrick, "Equity-Based Resource and Service Allocation for the City of San Josés Department of Parks, Recreation and Neighborhood Services" (2020). Master's Projects. 943.

DOI: https://doi.org/10.31979/etd.u6zq-6a88

https://scholarworks.sjsu.edu/etd_projects/943

This Master's Project is brought to you for free and open access by the Master's Theses and Graduate Research at SJSU ScholarWorks. It has been accepted for inclusion in Master's Projects by an authorized administrator of SJSU ScholarWorks. For more information, please contact scholarworks@sjsu.edu. 


\title{
Equity-Based Resource and Service Allocation for the
}

\section{City of San José's Department of Parks, Recreation and Neighborhood Services}

\author{
by \\ Patrick Córdova
}

\begin{abstract}
A Thesis Quality Research Project
Submitted in Partial Fulfillment of the

Requirements for the

Master's degree

in

PUBLIC ADMINISTRATION

Professor Frances L. Edwards, Ph.D.

Adviser
\end{abstract}

The Graduate School

San José State University

May 2020 


\section{TABLE OF CONTENTS}

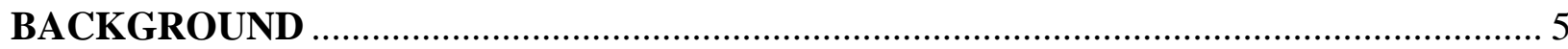

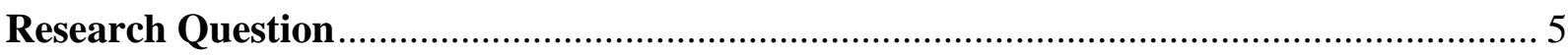

The City of San Jose's Budget Process ........................................................................... 5

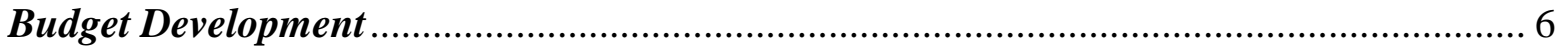

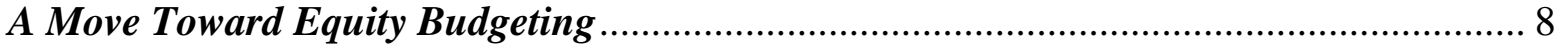

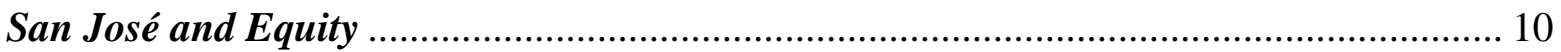

Equity Budgeting in the Department of Parks, Recreation and Neighborhood Services (PRNS)

Steps in Building an Equity Model: Step 1 -Identify the Factors to be Analyzed

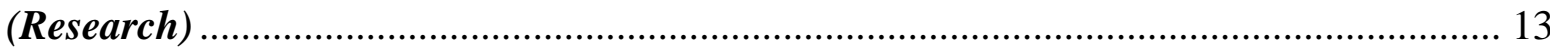

Steps in Building an Equity Model: Step 2 - Identify Source and Obtain the Data......... 14

Steps in Building an Equity Model: Step 3 - Analyze the Data ..................................... 14

Steps in Building an Equity Model: Step 4 - Making Data Actionable .......................... 17

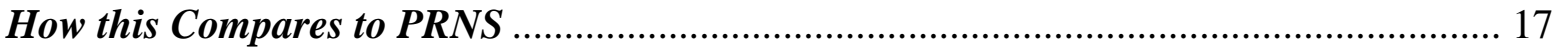

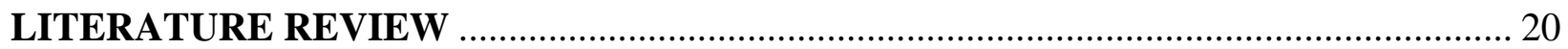

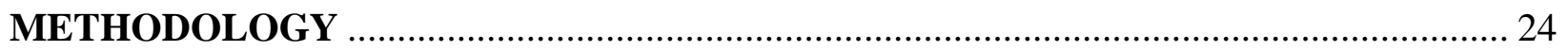

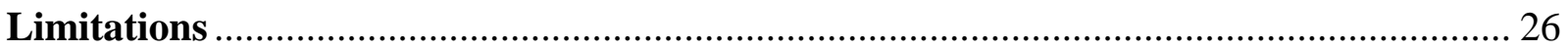

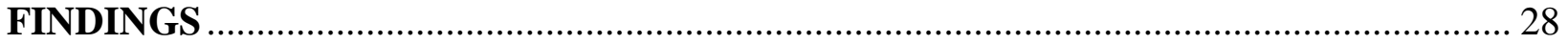

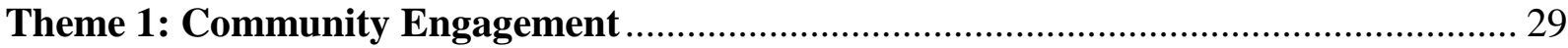

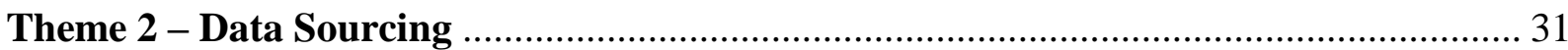

Theme 3 - Involvement of Race in the Framework/Work Plan .................................. 33

Theme 4 - Involving Internal Stakeholders............................................................ 35

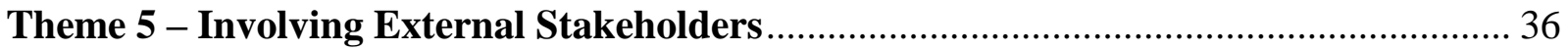

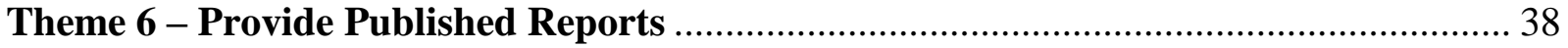

Theme 7 - Provide a Form of Methodology ................................................................ 39

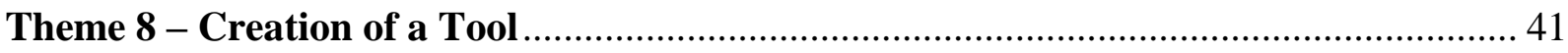

Theme 9 - Passing of Legislation to Support Equity Work ........................................ 43 
Córdova | Equity-Based Resource and Service Allocation

Theme 10 - Creation of an Office or Department Specific to Equity ............................ 44

Theme 11 - Data: Economic Indicators .................................................................... 45

Theme 12 - Data: Neighborhood Level(s) ........................................................... 46

Theme 13 - Data: Criminal Justice ......................................................................... 48

Theme 14 - Data: Education Level(s) .................................................................... 49

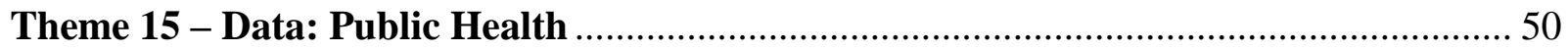

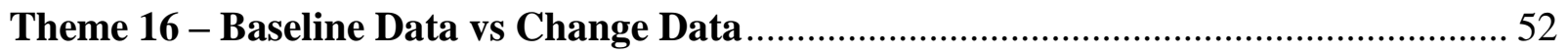

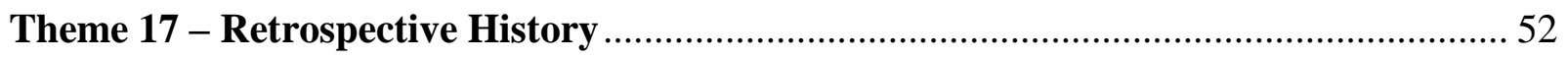

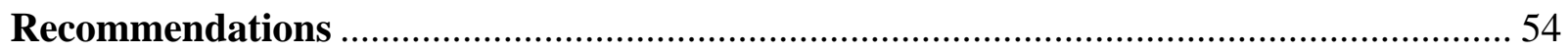

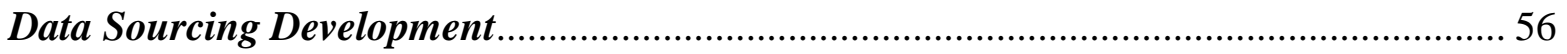

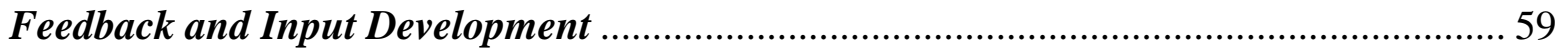

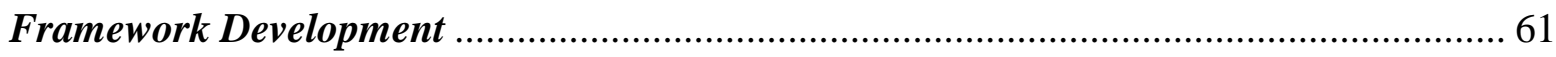

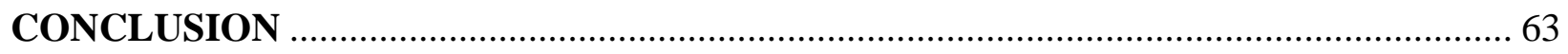

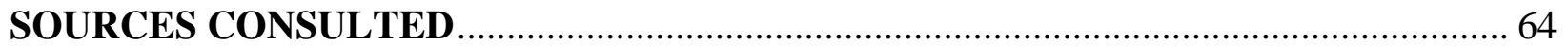


3 | P a g e

May 2020

Córdova | Equity-Based Resource and Service Allocation

\section{LIST OF FIGURES}

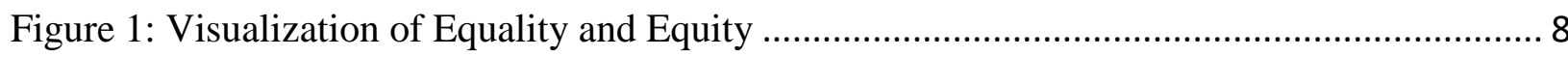

Figure 2: Visualization \#2 of Equality and Equity ………................................................. 9

Figure 3: Equity-Based Services of San Francisco DCYF ....................................................... 16

Figure 4: Methodology for Dallas Equity Indicators ................................................................. 40

Figure 5: San Francisco Resident Response (Sense of Safety)..................................................... 48

Figure 6: City of Dallas Education Indicator Success ............................................................ 50

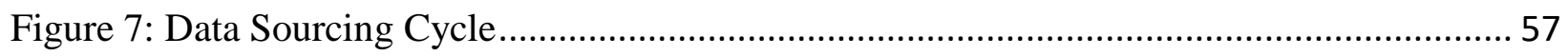

Figure 8: 2019 Citywide Scholarship Dashboard GIS Map …………...................................... 58

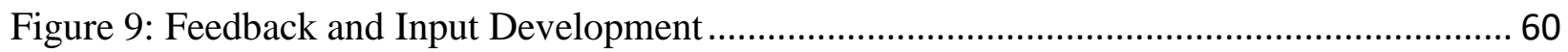

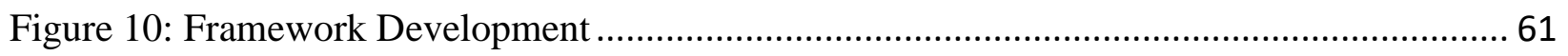


4 | P a g e

May 2020

Córdova | Equity-Based Resource and Service Allocation

\section{LIST OF TABLES}

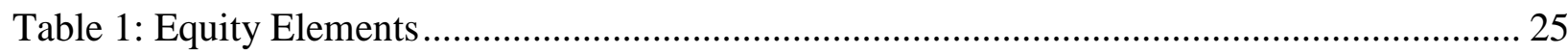

Table 2: List of Themes Along with Number of Agencies Using Each ................................. 28

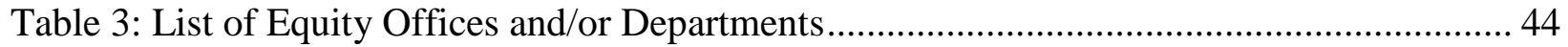

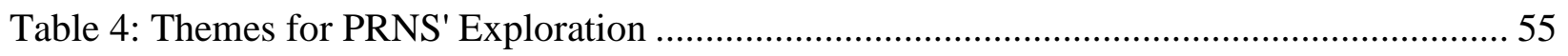

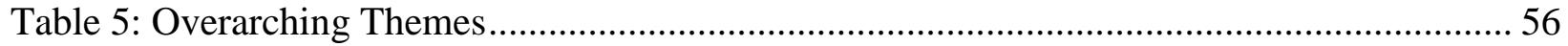


5 | P a g e

May 2020

Córdova | Equity-Based Resource and Service Allocation

\section{BACKGROUND}

The City of San José is the $10^{\text {th }}$ largest city in the United States and is viewed as a progressive regional leader in how it manages its services and resources, receiving recognition and awards from multiple organizations, including the State of California (Sykes, 2019). With direction from the mayor and city council, the city manager is tasked with developing a balanced budget on an annual basis, considering both ongoing and one-time expenses. The city has an operating budget of approximately $\$ 1.5$ billion in the general fund that serves over one million residents (Sykes, 2019). The general fund is the source of financial support for the operating expenses that provide community services. San Jose is considering how to allocate scarce public funding for community services with a new focus on equity.

\section{Research Question}

The purpose of this research is to examine the literature and public agency practice to understand how public agencies are using equity to allocate funding for services to provide an adequate level of service to stakeholders based on need. The research question is, based on existing research and other governmental agency models, how can the City of San José's Department of Parks, Recreation, and Neighborhood Services (PRNS) develop guidelines to allocate its resources within an equity-based framework?

\section{The City of San Jose's Budget Process}

San Jose has 27 departments. One department within the city is the Department of Parks, Recreation and Neighborhood Services (PRNS). PRNS has a general fund budget of almost $\$ 113$ million, or approximately $10 \%$ of the city's general fund expenditures for the 2019-2020 fiscal 
6 | P a g e

May 2020

Córdova | Equity-Based Resource and Service Allocation

year. Employing 768 full-time equivalent positions, PRNS provides an array of services ranging from offering senior nutrition programs and early education, to park maintenance.

\section{Budget Development}

There are multiple points in the year when PRNS can request budgetary actions from the City Manager's Budget Office. The city manager's annual budget report to the city council is a time when PRNS can request action to reconcile the budget and reallocate funds from the previous year, or to take credit for revenue it did not previously anticipate. This report is usually presented in October. The mid-year process is an opportunity to reconcile actual expenditures and revenue with budgeted expenditures and revenue, in the current fiscal year. As part of this process, PRNS can request additional funds for expenses that have recently changed, such as a newly executed contractual service with a higher than expected expense rate.

The annual operating budget development affects the following fiscal year. On an annual basis, PRNS strategically reviews its current allocated budget and identifies areas of opportunity and growth that could benefit from additional funds. This review begins each November in preparation for the adopted budget in June. All Departments review one-time funds and analyze whether to request to continue them; review areas of current ongoing budgetary items that require additional funding; and finally, review items that are currently not funded that PRNS requires in order to successfully produce or offer a service. These turn into budget proposals that are vetted through PRNS's leadership, and ultimately submitted for review to the city manager's Budget Office. These requests, if approved, then make it into the city manager's Proposed Operating Budget. 
7 | P a g e

May 2020

Córdova | Equity-Based Resource and Service Allocation

When the mayor and city council review the proposed budget, they then add requests for services, programs, and resources that they deem necessary for their constituents. These types of requests are sometimes one-time, but can become an ongoing service provided by PRNS as expected and anticipated by the residents. In his June Budget Message, the mayor recommends to the city council what items should be approved and how much revenue to allocate to them. The approved items become part of the City Manager's Adopted Operating Budget, which must be approved by the mayor and city council through a resolution.

The importance behind knowing the process is that these are the only times when a department can request modifications to its budget. Currently, the budget is distributed by continuing the same funding allocation to the community center or park district that was received last year (with the exception of requested modifications, poor performance on reported measures, or to keep pace with living wages in San José). There is no true analysis done to the current budgeted items except for those for which modifications are being requested. For example, the budget that a community center receives for purchasing supplies and materials will remain the same year-over-year unless PRNS requests additional or less funds for any reason, such as changes to meet increasing resident demands for services.

PRNS's budget is not currently dictated by the geographic location of the facility, the surrounding neighborhood's socio-economic makeup, or census tract median income. If a community center received $\$ 300$ for professional services in the previous budget, it will most likely receive $\$ 300$ the following year unless it requests to modify it. This means that specific areas or neighborhoods that received funds one year are typically able to expect to receive the 
8| P a g e

May 2020

Córdova | Equity-Based Resource and Service Allocation

same level of funding the next year. There is currently no equity lens being applied to PRNS's budget development process, because such an approach has not been adopted.

\section{A Move Toward Equity Budgeting}

The budget figures and process are important to note in this research, as they have become the center of a conversation that the mayor, city council, state assemblymembers, and other jurisdictions are having about the concept of equity-based budgeting. It is important, however, to note that there is a big difference between the concepts of equity and equality as shown in Figure 1 (Su, 2016).

\section{Figure 1: Visualization of Equality and Equity}

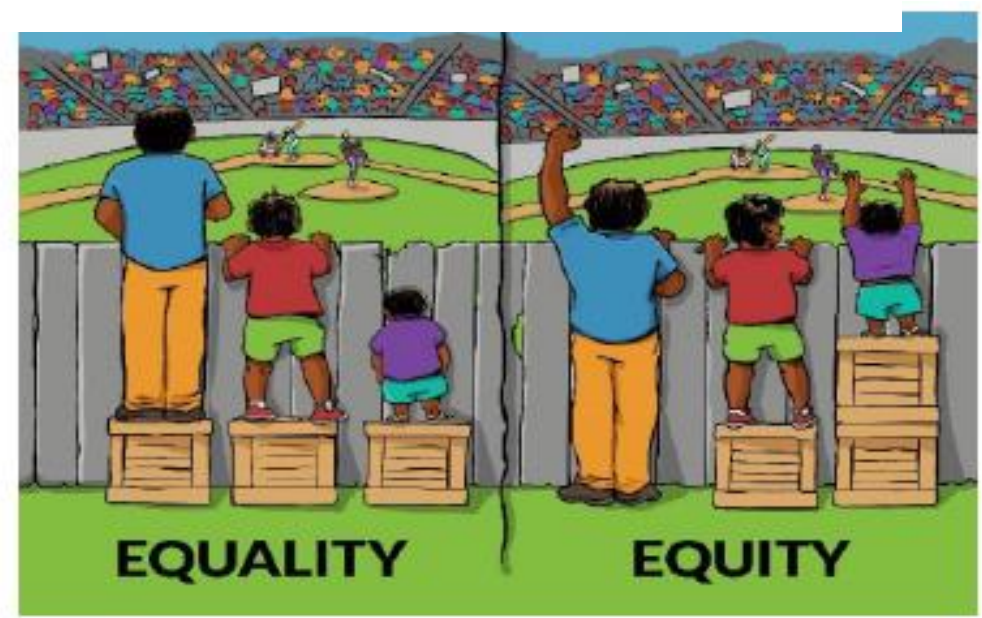

Source: Interaction Institute for Social Change / Artist: Angus Maguire.

Source: Maguire, 2016.

GIZ's (2018) Equity Budgeting Tool notes the following: "Equality describes the quality of things being the same, while equity denotes fairness. There are many different concepts of fairness, but all share the same notion of equality in some domain, such as rights, income, 
9 | P a g e

May 2020

Córdova | Equity-Based Resource and Service Allocation

wealth, access, opportunity, wellbeing, outcomes, or effort. The pursuit of equity means tackling differences that are seen to be unfair or unjust" (p. 11).

The definition of equality means that everybody gets the same size slice of the pie;

nobody gets more than the other, nobody gets less than the other. The concept of equity is much different from that. Equity, in concept, means that everyone receives just the right amount that he or she needs, based on whatever criteria have been set. For example, if a grocery store used equity in its pricing, people with the lowest incomes would pay the lowest prices for the product, while those with higher incomes would pay more. In reality stores use equality in pricing; it does not matter how much income the customer receives, he or she will expect to pay the same price as the next person for the same product when shopping at the same grocery store. The terms equality and equity are sometimes used interchangeably but are vastly different in operation.

\section{Figure 2: Visualization \#2 of Equality and Equity}

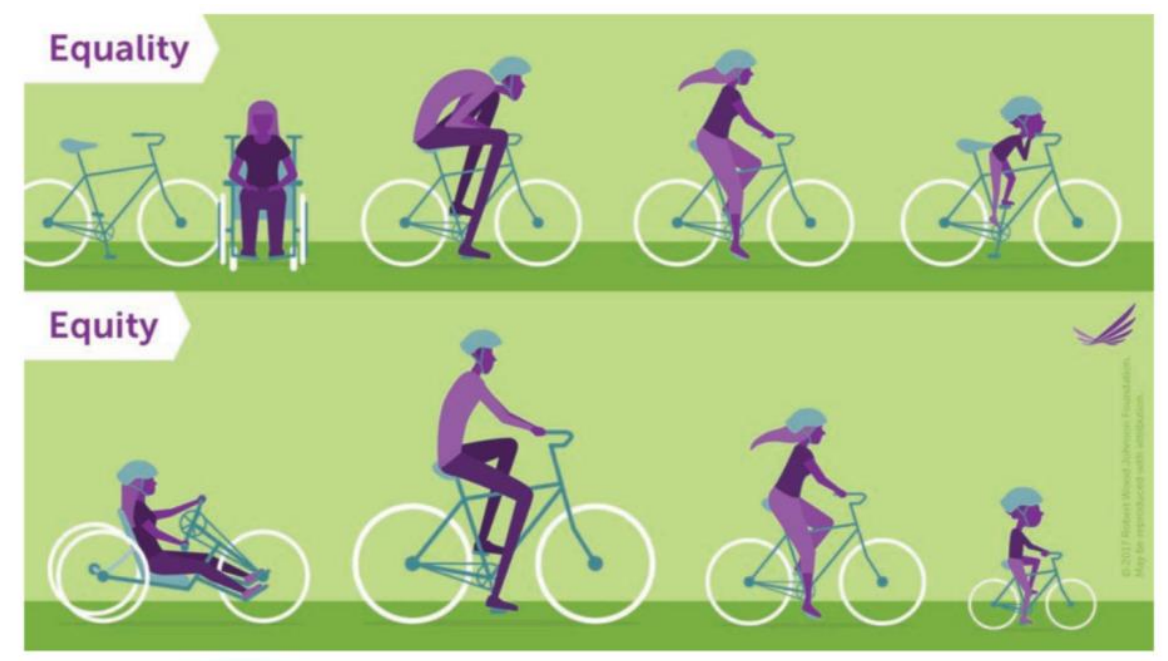

\section{Source: Robert Wood Johnson Foundation, 2017.}


$10 \mid \mathrm{P}$ a g e

May 2020

Córdova | Equity-Based Resource and Service Allocation

In essence, equity-based budgeting would require the city, and hence PRNS, to allocate resources and services based on measures of need. More and more public jurisdictions are beginning to identify the inequity in access and use of government services, and these jurisdictions assert that a change is needed (Riccuci, 2009; Bernabei, 2017; Su, 2017). As asserted by the Government Alliance on Race and Equity (GARE), equity and racial equity are items that should be at the focal point of government decisions allocating funds to programs in the budget (Nelson and Brooks, 2016). GARE is a national network of government agencies, ranging from the West Coast to the East Coast, focused on exploring the government's role in the building of racial equity in the public sector framework. Bay Area governments that are members of GARE include the City and County of San Francisco, City of Oakland, County of Santa Clara and the City of San José.

\section{San José and Equity}

The City of San José has identified equity as an essential criterion in policy making in order for cities to thrive and meet the demands of all of their residents (Peralez, Jimenez, Carrasco, Esparza, Arenas, 2019). While staff members of the City of San José agree that equity is an important factor in the distribution of government assets, there is no clear definition of equity or mechanism for achieving equity in the delivery of services. Mayor Sam Liccardo has spoken about the importance of equitable distribution of scarce government resources among city residents according to their level of need, calling for an "equity screen" to be developed and implemented to better serve residents (Liccardo, 2019). During the June 2019 city council meeting to approve the Adopted Operating Budget, five of the ten councilmembers issued a memorandum requesting the creation of a new ongoing $\$ 500,000$ Equity Fund, holding study sessions aimed at learning how other jurisdictions are successfully implementing this framework 
11 | P a g e

May 2020

Córdova | Equity-Based Resource and Service Allocation

of equity-based service allocation, and development of a concrete framework for the City of San José to use in its 2020-2021 Adopted Operating Budget Development Cycle (Peralez, Jimenez, Carrasco, Esparza, Arenas, 2019). The Mayor, however, was not comfortable with setting aside the amount of funding requested in the councilmembers' memo to create an Equity Fund without guidelines or a framework to guide the allocation. After seven hours of debate, all parties realized that they were nowhere close to establishing an equity lens, or even defining what equity was.

The city council decided to hold study sessions on the matter, while senior-level and executive staff worked to identify the best methods to incorporate equity in the allocation of services. These study sessions will include an examination of how other cities and public agencies have implemented equity-based budgeting; consultation with City of San José staff that are a part of the city's GARE cohort; and, information regarding what practices the city can actually implement as a municipality, or what constraints it may have legally. These different parties will come to the City of San José's study session and present on whether it is possible to incorporate an equity lens in its budgeting practices, and how to define criteria to guide budgeting decisions.

\section{Equity Budgeting in the Department of Parks, Recreation and Neighborhood Services (PRNS)}

PRNS is now faced with the difficult decision of whether it should incorporate equity into resource allocation requests. PRNS will have to analyze the different sources of funds that it has, the populations it serves, and, identify criteria to use to determine which neighborhoods within the city limits would be considered areas of higher need to develop the equity lens. Political 
12 | P a g e

May 2020

Córdova | Equity-Based Resource and Service Allocation

pressure is part of this type of analysis and decision making, but there are currently models that exist that may be able to assist PRNS in shaping its choice.

For the purpose of this research study, only funds that directly impact residents will be considered for equity-based distribution. For PRNS, the types of programs being considered are those allocated to community centers, direct services, and programs. For example, funds allocated to fitness or preschool classes will be considered for equity distribution, but not funds allocated for park maintenance, capital infrastructure programs or internal administrative services, as those are indirect benefits realized by all residents. While PRNS can explore using a model that takes allocations from areas with more high-income residents and gives that funding to areas with lower-income residents, it would have to consider the legal and political implications that such a decision may have. PRNS can also change its funding model to make the community centers and programs that are in traditionally/historically low-income areas more dependent on the General Fund, and the areas that traditionally/historically have higher-income residents more dependent on the revenue generated from its programming. While it may be desirable to create a formula using different factors and elements to generate a funding level for programs, there is no "gold standard" for equity-based budgeting, and no one formula to resolve PRNS's equitable distribution challenge. The research that currently exists shows that there are a variety of ways to incorporate equity-based budgeting, but selection has to be based on local political and legal realities. Though, varieties of ways exist, there are overarching themes that exist among the equity-based budgeting plans. Each plan starts at understanding that their agency must incorporate equity-based budgeting into their operations and build on that realization. After conducting an internal organizational review, these agencies or governments are able to identify 
13 | P a g e

May 2020

Córdova | Equity-Based Resource and Service Allocation

what areas of their operations they feel need to be altered in order to be more equitable (Curren, et. al., 2016). This leads them into their first step, research.

\section{Steps in Building an Equity Model: Step 1 -Identify the Factors to be Analyzed (Research)}

The methodology that many of the entities that incorporate equity-based budgeting or practices had in common was how they approached their decision-making process and identified the necessary criteria to be considered. All entities were able to identify that there was an issue with inequitable distributions of public resources in their service areas. The research shows that the first step towards creating an equity-based allocation framework is to identify what factors would be analyzed to create the equity screen (Rodriguez-Bolivar, et al., 2014; Beaulieu, 2001; Chakraborty and Blackburn, 2013; Lustig, 2011).

Using the example of earthquake risk mitigation, researchers looked at data pertaining to the condition, age, and seismic retrofitting of buildings. In addition, researchers also costed out the effects of debris clearing, reconstruction and ongoing expenses associated with locations near active fault lines (Zolfaghari and Peyghaleh, 2015). After identifying the appropriate categories to analyze, the researchers then identified which potential risk mitigation measures could be quantified in order to provide a means of comparison among multiple entities. In the example of earthquake risk mitigation, these measures range from present value of the building to types of utilities and amenities that the building has, and though they are two different items, they become comparable once the data is quantified (Zolfaghari and Peyghaleh, 2015). This is a commonality among much of the research: in order to compare factors that may be completely different, the factors must be quantified to create measures that can be used to compare 
14 | P a g e

May 2020

Córdova | Equity-Based Resource and Service Allocation

outcomes and trade-offs in equity-based distributions of resources (Lustig, 2011; Liscow, 2017;

Beaulieu, 2001).

\section{Steps in Building an Equity Model: Step 2 - Identify Source and Obtain the Data}

Once the factors or criteria are identified, the measures are assessed and categories of data one needs are identified, the research concludes that the next step that agencies involved in equity-based budgeting need to take is to obtain the data. This is, again, specific to the types of measures and categories identified by the research, and is needed in order to make entities, groups, or populations more comparable (Riccucci, 2009; Ruckert and Labonté, 2012). Of particular relevance to this study, there are jurisdictions with departments comparable to PRNS that have used the equity-based allocation approach and have results to justify the work. San Francisco's Department of Children, Youth, and their Families (DCYF) uses an equity-based allocation method to disburse its grant funds to community-based organizations that provide services to young people with the highest needs ( $\mathrm{Su}, 2016 ; \mathrm{Su}, 2017$ ). This program managed by DCYF is one of the better comparisons for PRNS to consider, as it provides educational, recreational, and social programming to young children, youth, and their families (Su, 2017). The targeted populations are also very similar to those found in San José, such as English learner, foster youth, LGBTQQ, and teen parent (Su, 2017). Initial research indicates that San José and San Francisco generally have similar demographics in the target populations (Peralez, et. al., 2019).

\section{Steps in Building an Equity Model: Step 3 - Analyze the Data}

DCYF obtains the data it needs by conducting a Community Needs Assessment, which identifies disparities between neighborhoods and population groups using different categorical 
15 | P a g e

May 2020

Córdova | Equity-Based Resource and Service Allocation

measures and data points, such as physical and emotional health of children and youth, children and youth who feel that they have caring families and neighborhoods, and their educational performance (Su, 2016; Su, 2017). This needs assessment allows DCYF to create its "priority populations," targeted populations from throughout the city with the highest equity disparity as compared to the rest of the city's residents. The needs assessment also uses town hall meetings to get firsthand information from the community members and neighborhood residents themselves on what services they believe are needed in their areas ( $\mathrm{Su}, 2016)$. These prioritized populations then receive a higher level of funding, services, and resources than residents who do not have an equity disparity (Su, 2016; Su, 2017). 
16 | P a g e

May 2020

Córdova | Equity-Based Resource and Service Allocation

\section{Figure 3: Equity-Based Services of San Francisco DCYF}

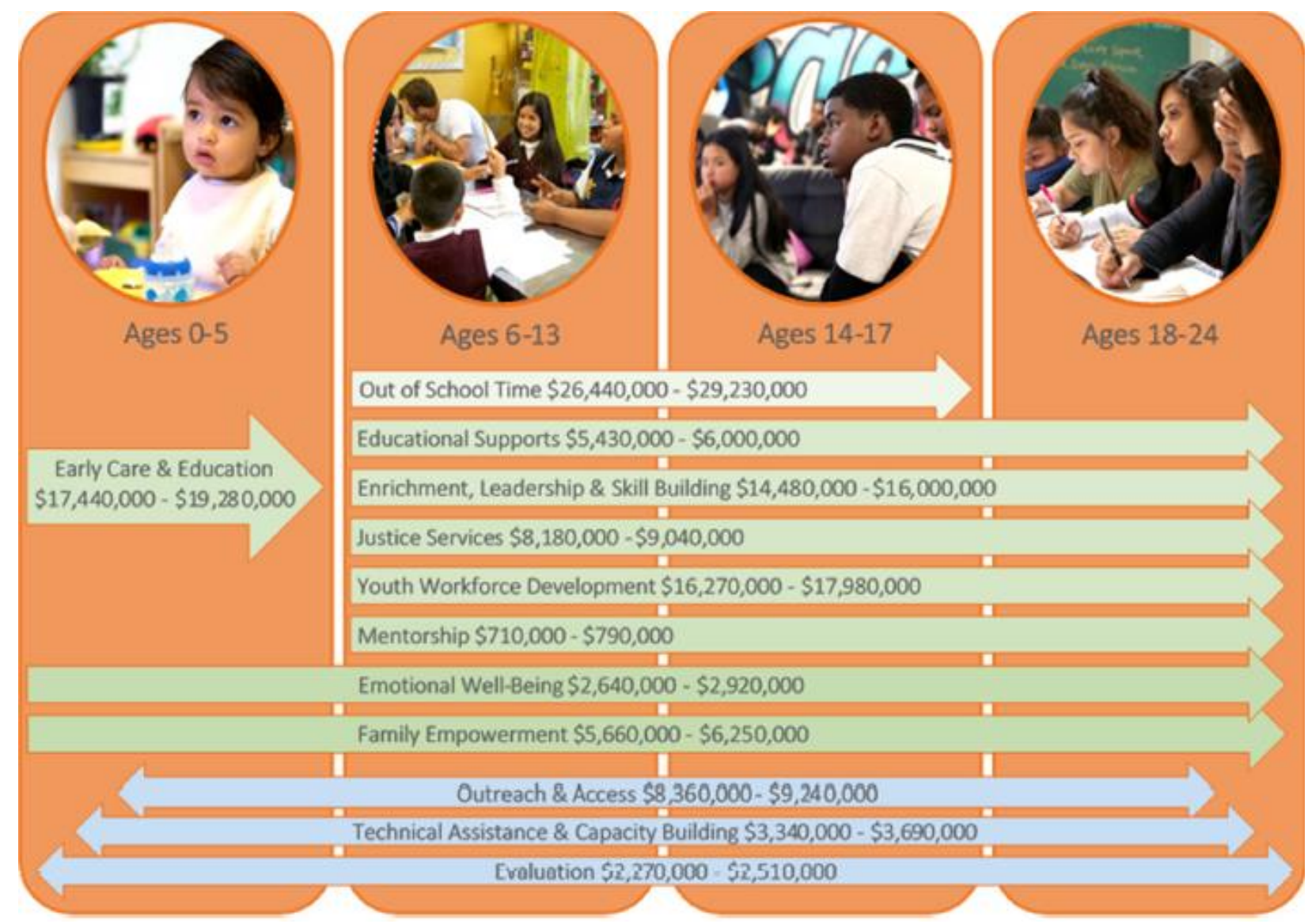

\section{Source: Su, 2017.}

This qualitative information and data mixed with the quantitative information allows

DCYF to work towards matching service providers to the areas and groups that want and need them (Su, 2016, Su, 2017). The information that comes out of these town hall meetings relates to the services that community members would like to see, and are broken out into age group services. The different types of services include early care and education for children 0-5, Out of School Time services for ages 6-17, and justice services for ages 6-24 (Su, 2017). These categories, represented in Figure 3, are service areas that the community-based organizations provide in the neighborhoods and to the populations of greatest need throughout San Francisco. 
17 | P a g e

May 2020

Córdova | Equity-Based Resource and Service Allocation

\section{Steps in Building an Equity Model: Step 4 -Making Data Actionable}

Though, the agencies studied agreed that there should be equitable changes to budgeting, the manner in which they made their data actionable differed. Climate change is one area that does not come to mind quickly when thinking of equitable-based budgeting or accountability, but it is a sector that has also made strides in this field of work. Researchers on climate change based their equitable distribution models on an individual per capita, historic impact in the country, the ability for the country to make payments, and whether or not that would impede the ability of that country to make any future improvements or developments (Mattoo and Subramanian, 2012). The equity screen or framework was addressed in the consequential relationship between a country's greenhouse gas emissions and how they are held accountable for it (Mattoo and Subramanian, 2012). As for the risk mitigation of earthquakes, the equitable lens was applied to the manner in which funds are distributed and allocated for reconstruction costs of damaged buildings in the region (Zolfaghari and Peyghaleh, 2015). These examples show that though there is an agreement in the literature as to the importance of equity, and about how to begin the process, there is no one true way in which agencies are carrying out the work (Lustig, 2011; Azong and Wilinska, 2017; Chakraborty and Blackburn, 2013). Studies have found that each model has a specific goal and targeted population, and related agencies have built their process around it; they have identified what the best method to address the issue is and how to best account for the allocation of funds, services, and/or resources in an equitable manner (Zolfaghari and Peyghaleh, 2015; Mattoo and Subramanian, 2011).

\section{How this Compares to PRNS}

There are many examples and research that show that here is a manner in which equity can find its way into resource allocating, but what does this mean and how is this applicable to 
18 | P a g e

May 2020

Córdova | Equity-Based Resource and Service Allocation

the needs of PRNS? Is this a worthwhile endeavor for PRNS to embark on, or could it be seen as a waste of time and effort? Is this something that PRNS could benefit from? DCYF is a local entity in the Bay Area region that may be able to shine some light on PRNS's questions, as there are many similar and comparable programs between the two entities. Is that enough though? Where PRNS must get creative if it decides to pursue equity-based budgeting, however, is how to disburse its existing funds, as they are not primarily grants like DCYF, but instead services, budgets, and program offerings that derive from the city's general fund. This research suggests that PRNS has factors similar to those that DCYF considers. Many of the factors and criteria that are shared exist in both governmental jurisdictions, and can be accessed for consideration. Both programs serve similar populations through similar means, as shown in Figure 3 (Su, 2017).

DCYF obtained information from the American Community Survey, from unified school districts, from county public health records, among other sources, in order to get a baseline of where its services and funding should go (Su, 2016; Su, 2017). These are all items that the City of San José and PRNS can explore. The difference, however, between the two jurisdictions will be how the resources get allocated. DCYF breaks down their service areas and has offerings similar to PRNS that include early care and education, out-of-school (afterschool) time programs, youth workforce development, and justice services as listed in Figure 3 (Su, 2017).

DCYF bases their allocation model on service areas more than population demographics. While still focusing on equity, the main topic is what type of services the different populations within the areas are lacking (Su, 2016). It aims to provide services in an equitable manner but also admits that part of the strategy is the balance of formula versus informed decisions. There are hurdles that even DCYF faces in allocating services equitably, for instance, there is no solid 
19 | P a g e

May 2020

Córdova | Equity-Based Resource and Service Allocation

proof for a way to allocate resources that will solve all the issues of equity in any given neighborhood or section of the city (Su, 2016; Su, 2017). For this exact reason, PRNS needs to take a broader look at a number of comparable entities using this model. PRNS needs to make more informed decisions based on existing models and research before it makes a determination on whether or not to create this framework. This study analyzed the existing models and research, and formulated a recommendation, or "road map", for PRNS to use to guide this endeavor.

The literature shows that there are many different ways to create an equity-based allocation/budgeting model, but if PRNS seeks to consider applying this lens to its current budgeting strategies, it must also consider what the real impact would be to its operations, staff, participants, and ultimately its resources. This initial implementation review has identified trends and patterns developed from public agencies in developing a similar framework and model that PRNS is evaluating. The next step would be for the data and research to be analyzed in order to formulate a recommendation for PRNS based on existing public agency models and the effectiveness realized. 


\section{LITERATURE REVIEW}

The concept of equity allocation of community resources is embedded in American political structures. For example, every property owner pays real estate tax based on some understanding of property value, a portion of which supports free public education in the political jurisdiction in which he or she lives. All children living in that political jurisdiction receive a free public education, regardless of whether the children's parents pay any real estate tax or not, so long as they are residents of the jurisdiction. This is just one form of what James Q. Wilson calls client politics, where everyone pays but a small group - in this case school-aged children - benefit (Rosenbloom, Kravchuk and Clerkin, 2014). This is the essence of equity politics at the local government level.

Though the City of San José and PRNS are in the early stages of developing resource allocation equity practices, there are many agencies and public entities that are currently practicing equity-based resource allocation. Local, state and federal jurisdictions are working on different ways to allocate services and funding in an equitable manner. There are different reasons for the variety of approaches, but many have initiated this conversation in order to meet the demand of their service users on the basis of need (Ruckert \& Labonté, 2012; Chakraborty \& Blackburn, 2013; Zolfaghari \& Peyghaleh, 2015). Equity is finding its way into many different jurisdictions; some are obvious, but others are in sectors that would not immediately come to mind. Researchers have investigated programs such as equitable resource allocation for risk mitigation of regional earthquakes, ensuring that health care services are provided in an equitable manner, and ensuring that the shared responsibility for human causes of climate change is distributed in an equitable manner (Ruckert and Labonté, 2012; Zolfaghari and Peyghaleh, 2015; 
21 I P a g e

May 2020

Córdova | Equity-Based Resource and Service Allocation

Mattoo and Subramanian, 2012; Weisman, et. al., 2018). Although the approaches and services vary, the literature concludes that equity may be a worthwhile lens to use to ensure that residents are receiving adequate services based on their need.

Research shows that there is a strong correlation between resource inequality and the social makeup of a given population (Arauco, et. al., 2014). Some of these factors have been found to be tied to the characteristics of a population that cannot be altered post-partum, including race, gender, and ethnicity (Arauco, et. al., 2014). These are factors that oppress populations but at times can spark social movements that may lead to changes within their country's political and resource allocation models. These changes are influenced by the creation of an equitable distribution model, or a model that is more inclusive of all populations not just those with economic power or political power (GIZ, 2018; Arauco, et. al., 2014). Though these elements are put into place to address the years of systematic oppression of these populations, it takes time for change in the allocation of resources to completely overturn the principles that once oppressed them. It takes time for countries and governments to come to the realization that they are not as fair or equitable as they once thought (Curren, et. al., 2016; Arauco, et. al., 2014). The theory of equity, itself, has gained an increase in attention on a global scale, and is being explored and analyzed by many countries (GIZ, 2018; Curren, et. al., 2016).

One of the central themes, consistent with the previous example of property taxes, is that some will end up receiving more resources, in quantity, than others, since it is based on the individual's need (GIZ, 2018). Government agencies that have attempted to implement this equitable lens have experienced backlash from those who are not viewed as the favored population (Curren, et. al., 2016; Bernabei, 2017). Research shows that the reason this backlash 
22 | P a g e

May 2020

Córdova | Equity-Based Resource and Service Allocation

has come to fruition can be correlated to the view that individuals were being stripped of their government resources because they had a high income, even though that is not what many felt about their given situation (Curren, et. al., 2016; Bernabei, 2017). This has been one of the harder revelations for governments to overcome, since it can be one of the more personal ones to whomever they are responsible for representing. It is one of the harder political choices that certain agency leaders have been forced to take (GIZ, 2018; Bernabei, 2017). This is a matter that has the potential to derail plans of government agencies due to the resistance that could be built up from their constituency. One thing, however, that is heavily backed by research is the fact that this resource and income inequality has existed in a pervasive manner for many decades prior to the interest in equity (Atkison, Piketty and Saez, 2011; Curren, et. al., 2016; Bernabei, 2017).

Research suggests that the income and power inequality has existed since the creation of the country, especially within the United States (Atkinson, Piketty and Saez, 2011). This disparity has further divided the population and has made the most vulnerable more dependent on public subsidies and resources. Although there has been an increase over time in the income levels, there has been a faster and more robust growth within the top wage earners than those in the moderate- or low-income brackets (Atkinson, Piketty and Saez, 2011; Arauco, et. al., 2014). In recent years, wages have grown rapidly and provided more benefit to those in the low-income brackets, however, moderate-income workers have seen much slower and marginal increases to their wages (Cox, 2019). The City of San José enacted policies to further assist the low-income workers, creating a Living Wage Policy for their employees and contracted employees (City of San José, 2014). This, however, still does not address those workers who earn moderate wages and may lead to further exacerbating the divide in wages. The notion of taking from some to give 
23 | P a g e

May 2020

Córdova | Equity-Based Resource and Service Allocation

to others is a hard concept or mentality to break through, so the messaging about the intent of doing so becomes more vital (Curren, et. al., 2016; Bernabei, 2017; Arauco, et. al., 2014). As in the previous example, when home owners are being charged property tax it is seen as an annoyance or nuisance or, at times, another way for the government to take from them. When the delivered messaging, however, of it being done and largely used to fund the education of any child in the public school system is received, there is less resistance than if it were to fund a government's special project (Rosenbloom, Kravchuk and Clerkin, 2014). The likelihood of the top wage earners to willingly let go of their earnings or resources reduces when the true intention for the use of those resources is poorly communicated, or not communicated at all. 


\section{METHODOLOGY}

The evaluation process that this research project will used is the Benchmarking Evaluation Process (Bardach, 2012). This process starts with identifying the problem, which is that the City of San José's councilmembers want the budget allocated using an equity-based approach. The second step is assembling evidence from other government agencies regarding resource allocation processes that implement an equity screen to allocate funds. The third step is to construct the alternative equity-based resource allocation models, and the fourth step is to select the criteria that will be used in San Jose. Steps five is to project the outcomes from this approach to budgeting, and step six is to confront any trade-offs that may be byproducts of creating this new resource allocation model. Step seven is to make a final recommendation for a model, and finally in step eight to explain why it would be the better model for the City of San José's PRNS to use in constructing its annual general fund budget recommendation.

The data that will be used in this research study are all from public agencies, ranging from local county and city entities to state and federal offices or departments. This study has identified the following entities to include in the benchmarking method:

- Santa Clara County Public Health

- San Francisco Department of Children, Youth, and Their Families

- City of Portland, Oregon

- City of Oakland, California

- City of Minneapolis, Minnesota
- City of Seattle, Washington

- King County, Washington

- City of Madison, Wisconsin

- City of San Antonio, Texas

- City of Dallas, Texas 
25 | P a g e

May 2020

Córdova | Equity-Based Resource and Service Allocation

This study will analyze these different entities' budgeting materials to identify categorical themes that exist among them, such as whether or not they conduct a community needs assessment prior to finalizing the model, identifying what data points they use, or whether they focus on certain categorical areas such as education, homelessness, or housing market. Table 1 demonstrates the benchmarking methodology, which will allow for patterns within their approaches to equity-based budgeting to be identified, and specified elements to be recommended to PRNS for its equity lens. While Table 1 illustrates some of the different elements that encompass the many themes found in different equity-based resource allocation plans, it is not all encompassing, as there are a variety of elements that each individual agency or government entity includes in its own plans.

Table 1: Equity Elements

\begin{tabular}{|l|l|l|l|l|}
\hline \multicolumn{1}{|c|}{$\begin{array}{c}\text { Equity Element in Budgeting } \\
\text { Tools }\end{array}$} & $\begin{array}{c}\text { GARE Equity } \\
\text { Toolkit }\end{array}$ & $\begin{array}{c}\text { City of San } \\
\text { Jose }\end{array}$ & $\begin{array}{c}\text { City of } \\
\text { Portland }\end{array}$ & $\begin{array}{c}\text { City of } \\
\text { Seattle }\end{array}$ \\
\hline Community Needs Assessment & & & & \\
\hline High School Graduation Rates & & & & \\
\hline Low Income Housing Percentage & & & & \\
\hline $\begin{array}{l}\text { Juvenile Probation/Incarceration } \\
\text { Rates }\end{array}$ & & & & \\
\hline
\end{tabular}

The project will use benchmarking to compile the equity data points and formalize a recommendation for the City of San José's PRNS to consider while weighing the trade-offs of such a model. The recommendation will include which areas are included in most of the equitybased resource allocation models, and what specifically PRNS can anticipate if implementing the model. 
26 | P a g e

May 2020

Córdova | Equity-Based Resource and Service Allocation

This project will be using the exclusion parameters from San José State University's Institutional Review Board's (IRB) process. The data that will be collected and analyzed is published, publicly accessible data gathered directly from the public agencies through their websites or department heads. This will include website material, methodology reports, and method of data collection for each respective public agency. Other data considered are meeting agendas and minutes, presentations to the public, and published reports on effectiveness. All demographic information needed to evaluate equity will be non-identifiable, such as data from the American Community Survey or United States Census. Since this study is a systematic one, contributes to generalizable knowledge and does not involve human subjects, and contains no identifiable information, it meets the threshold for an exclusion from IRB review.

\section{Limitations}

This research project was conducted by the compilation and analysis of published materials by the identified government agencies, as this is what the community would see. While this project considered including interviews and direct communication with heads of these agencies in its design, it ultimately took the first approach because of the community-level impact that is realized by the work surrounding equity-based resource allocation. Due to this, there were some agencies and jurisdictions that had more robust published materials in comparison to their counterparts that were identified as resources for this research project. There may be more robust materials, data, and information that exists internally to these agencies but they have not been published formally to the agency's websites. This research project, however, found a more comprehensive list of agencies that have been identified as exploring 
27 | P a g e

May 2020

Córdova | Equity-Based Resource and Service Allocation

implementation of equity-based resource allocation. The final list of data sources was determined by the amount of published material that was publicly available.

Another major limitation to this research project is that this field of study and research is in the early stages of its development. With the exception of Seattle, which began this work in 2004, a very small number of agencies had started to explore and begin the development of explicitly labeled equity-based resource and service allocation, with an even more limited number of agencies having implemented fully functioning frameworks or work plans. Due to this, there is a scarcity in resources and research material that makes it a bit harder to weigh the pros and cons of equity-based resource and service allocation. There is, however, a national network of public agencies and sectors that are involved with the Government Alliance on Race and Equity (GARE) whose sole mission is to bring race, equity, and racial equity to the forefront of government program development and policymaking. There are a number of agencies that have no more than three to five years of experience in developing equity frameworks and work plans that will be able to supplement the findings that the City of Seattle has already compiled. 


\section{FINDINGS}

The goal of this research was to discover commonly used methods for developing plans on how to use equity in the allocation of public funds for community services. The research reviewed reports, tools, and other documents produced by the governmental agencies that highlighted the equity work they do, as well as how the agencies created their approach. Among the ten agencies, the research found seventeen commonalities, or themes, with twelve of these themes being shared with at least seven of the agencies.

Table 2: List of Themes Along with Number of Agencies Using Each

\begin{tabular}{|l|l|}
$\begin{array}{l}\text { 1. Community Engagement }-10 \\
\text { 2. Data Sourcing }-10\end{array}$ & $\begin{array}{l}\text { 10. Creation of an Office or Department } \\
\text { Specific to Equity Work }-7\end{array}$ \\
$\begin{array}{l}\text { 3. Involvement of Race }-10 \\
\text { 11. Data: Economic Indicators }-7\end{array}$ \\
$\begin{array}{ll}\text { 5. Involving Internal Partners }-10 & \text { 12. Data: Neighborhood Level(s) }-7 \\
\text { 6. Providing Public Report Outs }-9 & \text { 13. Data: Criminal Justice }-6\end{array}$ \\
$\begin{array}{ll}\text { 7. Provides a Methodology }-9 & \text { 14. Data: Education Level(s) }-6 \\
\text { 8. Creation of a Tool }-7 & \text { 15. Data: Public Health }-6 \\
\text { 9. Legislation to Support the Work }-7 & \text { 16. Baseline vs Change Data }-5\end{array}$ \\
\hline
\end{tabular}

There were five themes that all agencies shared in common, which highlighted the importance of them in the creation of a plan to implement equity-based resource allocation. These five themes were: 1) Community Engagement, 2) Data Sourcing, 3) Involvement of Race, 4) Utilization of Internal and 5) External Stakeholders. All of the agencies used each of these 
29 | P a g e

May 2020

Córdova | Equity-Based Resource and Service Allocation

themes in one way or another, and alluded to the importance of each element. Each of the additional themes and elements were still prevalent in many of the agency plans but varied in their approach and use. In a holistic view, however, each of the seventeen elements provided sound insight into the developments of the agencies' respective plans, and warrant consideration by PRNS.

\section{Theme 1: Community Engagement}

The theme of community engagement was prevalent and a strong foundation in all of the reports, tools and documents published by the ten governmental agencies. Many of the agencies state that they were embarking on this equity framework in order to end systematic and historical institutions of racism that have existed in their jurisdictions for decades (City of Seattle, 2008; City of Seattle, 2015; Hendricks, et. al., 2017; Beatty and Foster, 2015; Wheeler and Dessou, 2018). The work of equity-based resource allocation or governmental decision-making was being done for the good of the community, and in order to end systematic oppression, which meant that a large component from it needed to be the voice of the community. San Francisco's Department of Children, Youth, and their Families (DCYF) creates their work plan heavily on the input they receive from the community.

DCYF manages a fund that supports and awards grants to community-based organizations that provide services and/or programs to the community. Many of these services are provided to the more vulnerable populations at little- to no-cost, and range from educational afterschool programming, or recreational programming such as basketball (Su, 2016; Su, 2017). Every three years, DCYF conducts a community needs assessment that involves holding community listening sessions or town-hall meetings, to gather information and feedback from 
30 | P a g e

May 2020

Córdova | Equity-Based Resource and Service Allocation

the community members on what programs are needed but lacking in their neighborhoods $(\mathrm{Su}$; 2016). DCYF compiles all of these responses, then conducts an analysis of what services are currently being offered in those neighborhoods, and compares it to the community's feedback. The ultimate product of this, in addition to other criterion, is the creation of a funding plan to allocate resources to these neighborhoods in order to address the needs of the community ( $\mathrm{Su}$, 2016; Su, 2017).

Other jurisdictions use the same approach in the development and formation of their equity-based plans. The City of Madison, Wisconsin uses community input in order to make policy and/or programmatic decisions (City of Madison, 2019). Their tool's four-step approach has many points at which the department using the tool must incorporate community input and engagement. These points include the initial review of best practices, prior to making a decision on the program or policy, to the actual decision making. The city requires this input in order to verify that vulnerable or minority populations will not be unintentionally negatively affected by the change (City of Madison, 2019). The City of San Antonio has built this into their Budget Equity Tool as well, as it states that the tool is designed to allow the community to have a more active role within the decision-making process in the budget development process (City of San Antonio, 2019).

The ten governmental agencies have changed their approach to incorporate the voice of the community in decision-making and feedback looping. They have built a coalition with the community and have allowed it to weigh the pros and cons of the respective agency's program or policy-development or change process (City of Minneapolis, 2019; Fenstersheib, Peddycord and Ferrer, 2011). The City of Seattle views this as weighing and determining the benefit and burden 
31 I P a g e

May 2020

Córdova | Equity-Based Resource and Service Allocation

created by such change (City of Seattle, 2019). This method or approach allows for the creation of checks-and-balances between the community themselves and their respective government. It allows for the community to ensure that their voice is heard, and that those marginalized or vulnerable populations do not continue to be oppressed, knowingly or unknowingly, through the bureaucratic process of policy, program, or budget development (County of Santa Clara, 2019; City of Seattle, 2011; City of San Antonio, 2019; Hendricks, et. al., 20017).

\section{Theme 2 - Data Sourcing}

All ten governmental agencies emphasized the need for and importance of incorporating data in order to make data-informed decisions (Beatty and Foster, 2015; Belgarde, et. al., 2016; City of Dallas, 2019; City of Oakland, 2018; Su, 2016). Data needs to be at the center of any decision making, development, improvement, change or implementation, especially when it deals with the equitable treatment of marginalized populations (Beatty and Foster, 2015; City of Seattle, 2008; Nelson and Brooks, 2016). Some of the factors that agencies must consider are whether or not the data is from a reliable source, of quality and the lifespan of that specific data source (City of Oakland, 2018). For example, if a government agency that is developing an equity plan from scratch decides to obtain data from a start-up nonprofit in their jurisdiction that does not seem as though they are reliable due to age, does not have fool proof data points to quantify from, and does not seem stable enough to have a long lifespan, the agency may be picking a data source that will not provide them with longevity adequate for their desired outcome. This is not to say, however, that this will always be the case, as community makeup can change from year-to-year, meaning that consistency in the reporting from the same community members may change as well. Community feedback still remains an important and crucial data source for agencies, as they are directly impacted by these changes, and the 
32 | P a g e

May 2020

Córdova | Equity-Based Resource and Service Allocation

implementation of such efforts and initiatives (City of Minneapolis, 2019; Cummings, 2019; City of Seattle, 2008). The data sources that are utilized by the ten agencies are largely the same and, at many instances, come from the same source.

The type of data points varied among the agencies in this research, and some will be explained in detail in the latter portion of the findings, but the sources from which these agencies obtained the data all were very similar. One entity that each agency relied on was the United States Census Bureau. The Census Bureau tracks population throughout the United States, recording specific demographics such as race/ethnicity, income levels, those living in or under the poverty line, and size of the household. These data points were poignantly emphasized in the research, as it is important to note the demographics of a jurisdiction when creating an equity framework. Noting such information has helped agencies disaggregate the information regarding race/ethnicity, age, gender and more. The goal of many of these agencies' equity work plan was to end the systematic oppression of specific populations, mainly populations of color, so they need to know whether their jurisdiction has representation from those populations.

Another very common data source in this research was that of a jurisdiction's education levels. These data points usually came from the state's and county's respective education agency and school districts that serve residents of the given jurisdiction. The importance of obtaining data from education-related districts is explained in further detail in the "Theme 14-Data: Education Level(s)" but the importance of this source is seen throughout the ten agencies. Many of the agencies have made education a focal point, and one of the guiding principles of their equity framework and work plan (City of Oakland, 2018; City of Dallas, 2019; Beatty and Foster, 2015). In addition, while not all have made it a focal point, the agencies have also made a 
33 | P a g e

May 2020

Córdova | Equity-Based Resource and Service Allocation

concerted effort to obtain data from their local Public Health Department and Police

Department/Court System.

One challenge that persists, in addition to the selection of data sources, is that the compilation, analysis, and at times creation of datasets is an ongoing necessary task that needs to occur. Since data may change over years or reporting periods, agencies must commit to always using the new data in order to successfully implement a data-driven equity framework and work plan. King County understands the importance of using new data, and at times creating their own data sets from information that they gather, but has recognized it as a limitation or challenge, since the analysis and compilation of these data points requires a commitment, which also comes with a financial commitment over time (Beatty and Foster, 2015).

\section{Theme 3 - Involvement of Race in the Framework/Work Plan}

This topic has potential to be one of the more controversial or politically sensitive themes out of the seventeen identified themes, and connects indirectly with "Theme 16-Retrospective History." The topic of race has been a topic that not many have wanted to address, and research shows that many times it is because it requires the agency to admit that they were wrong and had implemented systematic and institutionalized oppressive programs, policies, or initiatives, whether unintentional or not (City of Seattle, 2008; City of Dallas, 2019; City of Oakland, 2018; Hendricks, et. al., 2017). In 2004, the City of Seattle became the first government jurisdiction to admit the faults in the city's historical failures to adequately serve the minority population, and explicitly declared an initiative and work plan to address racial inequities within the city's system (City of Seattle, 2008; City of Seattle, 2011; Belgarde, et. al., 2016). The city understood that there was going to be backlash and ill sentiments towards this outright decision and 
34 | P a g e

May 2020

Córdova | Equity-Based Resource and Service Allocation

communication, but stated that there was no way that they could truly address the inequities in their jurisdiction without addressing the disparities created from systematic and institutionalized racism (City of Seattle, 2008). Two San Francisco Bay Area jurisdictions, the City of Oakland and Santa Clara County Public Health Department, emphasized the importance of race and racial equity in their respective work plans.

The Santa Clara County Public Health Department reported that one of their key findings was that race and ethnicity had a high correlation with the health, socioeconomic status, and access to resources of populations of color (Fenstersheib, Peddycord and Ferrer, 2011). The report also highlights the differences in policymaking and program development, and the disparities created for populations due to focusing on individualistic approaches, which is further discussed in "Theme 15 - Data: Public Health" (Fenstersheib, Peddycord and Ferrer, 2011). The City of Oakland stated that "race matters" and made this a focal point in their jurisdiction's equity framework and work plan (City of Oakland, 2018, page 8). Their claim was supported by their research and data, as many of the measurements and data points demonstrated a wide disparity between populations of color and the white population (City of Oakland, 2018; Cummings, 2019). The City of Oakland also emphasized the disparities that were created in their jurisdiction dating back to the mid- to late-1800's, before it was even a formal municipality. One example that the city used was the 1882 Chinese Exclusion Act, which was a nationwide immigration ban (City of Oakland, 2018).

While not as explicit as the aforementioned examples, all ten agencies demonstrated their stance on including racial inequities in their work plans. Creation of tools that included data on disparities between populations of color and their white counterparts were prevalent throughout 
35 | P a g e

May 2020

Córdova | Equity-Based Resource and Service Allocation

this research. The City of San Antonio has required departments to use their Budget Equity Tool, which aims to implement racial equity programming leading to an outcome in which race and ethnicity would not be able to predict the success or health of a given population (City of San Antonio, 2019). The City of Madison mandates that their departments use data on race to show change in disparity over time, and as a way to ensure that populations of color are not burdened by public policy and program development (City of Madison, 2019). Madison, Wisconsin has called their tool the "Racial Equity and Social Justice Tool." The City of Minneapolis has also followed suit with the City of Madison, naming their framework and work plan the "Strategic \& Racial Equity Action Plan” (City of Minneapolis, 2019; City of Minneapolis, 2020).

\section{Theme 4 - Involving Internal Stakeholders}

The involvement of internal city, county or department staff has been shown to improve the development of such a framework or work plans. Research shows that these entities involved multiple departments/offices within their structure, as well as staff, in order to not only build cohesion through work that crosses responsibilities, but also to further the agency's culture of building equity within all services and programs offered to the community (City of Oakland, 2018; City of San Antonio, 2019; City of Madison, 2019; City of Minneapolis, 2019).

In addition to the involvement of internal staff to build cohesion in the work and further the culture of promoting equity, some of the agencies used this as a checks and balance approach. The City of Madison required staff to send their final product of the tool to their department's leadership team, as well as to answer a survey that is created and managed by the Division of Racial Equity and Social Justice Initiative (City of Madison, 2019). The City of Portland requires each department within their jurisdiction to create a core team of staff in order 
36 | P a g e

May 2020

Córdova | Equity-Based Resource and Service Allocation

to administer and analyze the equity framework on an ongoing basis (Hendricks, et. al., 2017).

The creation of this core competency team allows for the city to ensure that equity is

continuously being built into the operations and development of every service it is offering to residents, ranging from parks and recreation to building and business permits (Hendricks, et. al., 2017).

\section{Theme 5 - Involving External Stakeholders}

In addition to involving internal staff and stakeholders, the research showed that there is significant benefit in the involvement of external stakeholders. The research shows the importance of using external stakeholders, such as community leaders, businesses, and nonprofits to further implement equity throughout the agency's jurisdiction. King County uses over thirty semi-structured interviews with both internal and external stakeholders to gather their opinions and thoughts about the equity work being done in the county (Beatty and Foster, 2015). The county uses these interviews in order to obtain qualitative feedback to supplement their data, because participants in these interviews, or focus groups, communicate different areas of opportunity or improvement for county provided services relating to equity (Beatty and Foster, 2015).

Other tool kits and resources state the importance of involving these stakeholders from the development phase and into the implementation and maintenance phases (Nelson and Brooks, 2016). In the initial phases of their equity framework and work plan development, the City of Seattle focused on services that they were delivering, and work plans of their respective departments. As their equity work plan continued, and they obtained more feedback and refinement, the City of Seattle began widening their service delivery and scope to include the 
37 | P a g e

May 2020

Córdova | Equity-Based Resource and Service Allocation

sectors for which they were not directly responsible (City of Seattle, 2011; City of Seattle, 2008;

Belgarde, et. al., 2016). The City of Dallas also implemented this type of planning, as it listed service areas that fell out of its purview, but at least were within the authority of a governmental agency that serves its residents (City of Dallas, 2019). The involvement of these external partners furthers the reach of the City of Dallas, which in turn furthers the reach of their equity work plan and service delivery (City of Dallas, 2019). The City of Oakland has extended this to other businesses and entities, such as the Major League Baseball team, the Oakland Athletics. In a proposal to build and develop a new ballpark, the Oakland Athletics submitted a proposal and report on how they would further equity in the effected neighborhoods (Cummings, 2019). The report highlighted current disparities and inequities among different populations and races/ethnicities within those given neighborhoods in an effort to create a baseline and demonstrate the effects of their outreach and service delivery (Cummings, 2019).

One agency that has seemed to become an expert in this is the San Francisco DCYF. Their entire service delivery, relating to equity, is the use of external partners and communitybased organizations and nonprofits to deliver the service of equity to the community ( $\mathrm{Su}, 2016$; $\mathrm{Su}, 2017)$. Since the agency acts as a funding mechanism for equity service delivery, it solely relies on external partnerships to deliver the programming ( $\mathrm{Su}, 2017)$. The agency conducts a competitive request for proposal process to select eligible external partners. That requires outreaching to external partners, recruiting, vetting, and ultimately creating a working relationship with these entities (Su, 2016; Su, 2017). The department has used this approach for the administering of their "Children and Youth Fund" to provide equity-based resources and services to their residents, from infants and children to youth and young adults. 
38 | P a g e

May 2020

Córdova | Equity-Based Resource and Service Allocation

Another method that was common in some of the ten agencies was the use of external partnerships with educational institutions to create their respective equity-based frameworks or work plans. The City of Dallas and City of Oakland utilized a partnership with the City University of New York's Institute for State \& Local Governance (CUNY-ISLG) to create their framework and work plan (City of Dallas, 2019; City of Oakland, 2018). The partnership with CUNY-ISLG has helped shape the manner in which the two agencies created their work plans. Each of the agencies used a methodology, scoring guide and algorithm for their indicators that was originally developed by CUNY-ISLG. These important parts of their work plans were already created but tailored to fit the needs of their community and populations (City of Dallas, 2019; City of Oakland, 2018).

\section{Theme 6 - Provide Published Reports}

One of the things that all government agencies and jurisdictions have in common is their obligation to remain a transparent entity among the public. Things such as the Brown Act or Public Records Act ensure transparency between the government and residents or its constituents, by giving ample time for the public to review documents and information being presented at City Council meetings, or allowing the community to obtain records on request, depending on the sensitivity of the material. Publishing reports of work plans, findings and results of the equity-based work is something that all but one jurisdiction have in common. Some agencies, like the City of Seattle, have multi-year work plans, for which they provide periodic updates and published reports at the end of the given time (City of Seattle, 2011; City of Seattle, 2015). These reports serve as a way to be held accountable to the mission of the equity development work, as well as to the community at-large. 
Other jurisdictions do not have as robust a work plan as the City of Seattle, but provide published reports, nonetheless. The City of Madison and City of San Antonio publish their tools in order to provide transparency to the community as to the process they use to reach decisions, or changes in policies or programs (City of Madison, 2019; City of San Antonio, 2019). Another overarching theme about these published reports is that the agencies provide the findings of all measures, whether positive or not. The City of Dallas and City of Oakland use a scoring mechanism that demonstrates how well, or not, they are doing at reaching equitable work in given areas (City of Dallas, 2019; City of Oakland, 2018). The City of Minneapolis publishes their reports on their website, and provides a status update periodically to their council, reporting on measures and indicator progress (City of Minneapolis, 2019; City of Minneapolis, 2020).

The lone entity that does not provide published reports on equity specifically is the County of Santa Clara, because it is an element of their work plan, not their guiding work plan (County of Santa Clara, 2019). Though it does not publish equity-specific work plans, the county does provide updates and framework specifically for "Racial and Health Equity," their guiding element for achieving health equity across their jurisdiction (County of Santa Clara, 2019). The county has a set of three objectives within their element of racial and health equity that is then split up to a total of eleven strategies to accomplish those goals.

\section{Theme 7 - Provide a Form of Methodology}

Another item that research has found helps to support the transparency of the government agency, as well as inform the community as to what it seeks to accomplish and how, is the detailed methodology that the agencies outline in their reports. The methodology pages for the agencies listed what they were going to do, how they were going to do it, who was going to be 
40 | P a g e

May 2020

Córdova | Equity-Based Resource and Service Allocation

impacted, what the data sources were, and how the findings were going to be accounted for. The figure below is an example from the work plan and report created by the City of Dallas that outlines their methodological guiding map.

\section{Figure 4: Methodology for Dallas Equity Indicators}

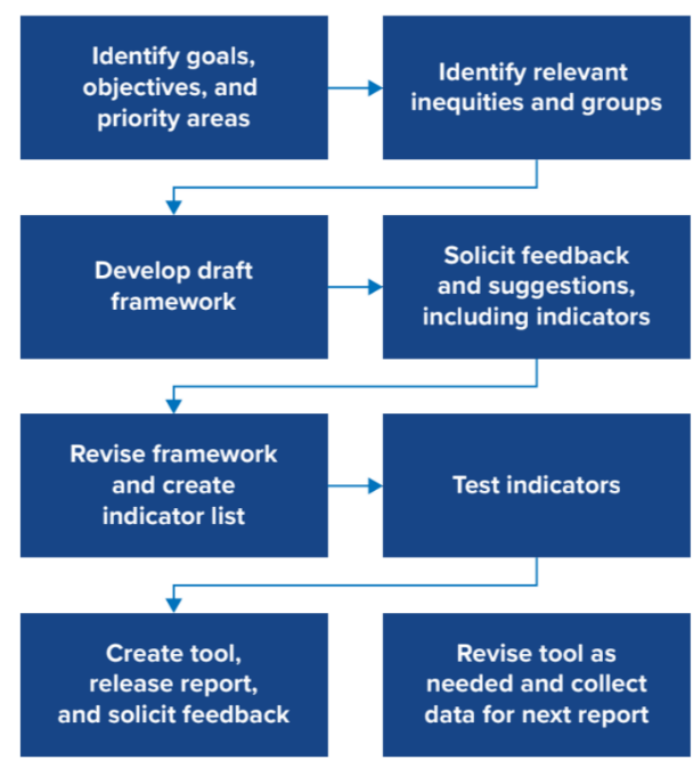

\section{Source: City of Dallas, 2019.}

The guiding map demonstrates the different aspects of the work plan, and as a whole provides a depiction to the community of the work that is being done by their government agency (City of Dallas, 2019). Other agencies, such as the City of Madison or City of San Antonio, that create tool kits instead, outline their methodology in each step of the tool kits to demonstrate the methodological steps needed to implement equity-based work in their city structure or services. Figure 5 demonstrates a generic step-by-step process cycle for the creation of a methodology based on this research project (City of Madison, 2019; City of San Antonio, 2019; Nelson and Brooks, 2016; County of Santa Clara, 2019; City of Seattle, 2019). Generally, these methodologies begin with the issue which leads the agency into obtaining the data, and 
41 I P a g e

May 2020

Córdova | Equity-Based Resource and Service Allocation

developing a plan to address the issue. After obtaining initial feedback, whether internal or external, the agency would then act to implement the measure, then evaluate and refine it after obtaining feedback post-implementation.

\section{Figure 5: Generic Methodology Cycle for Tool Kits}

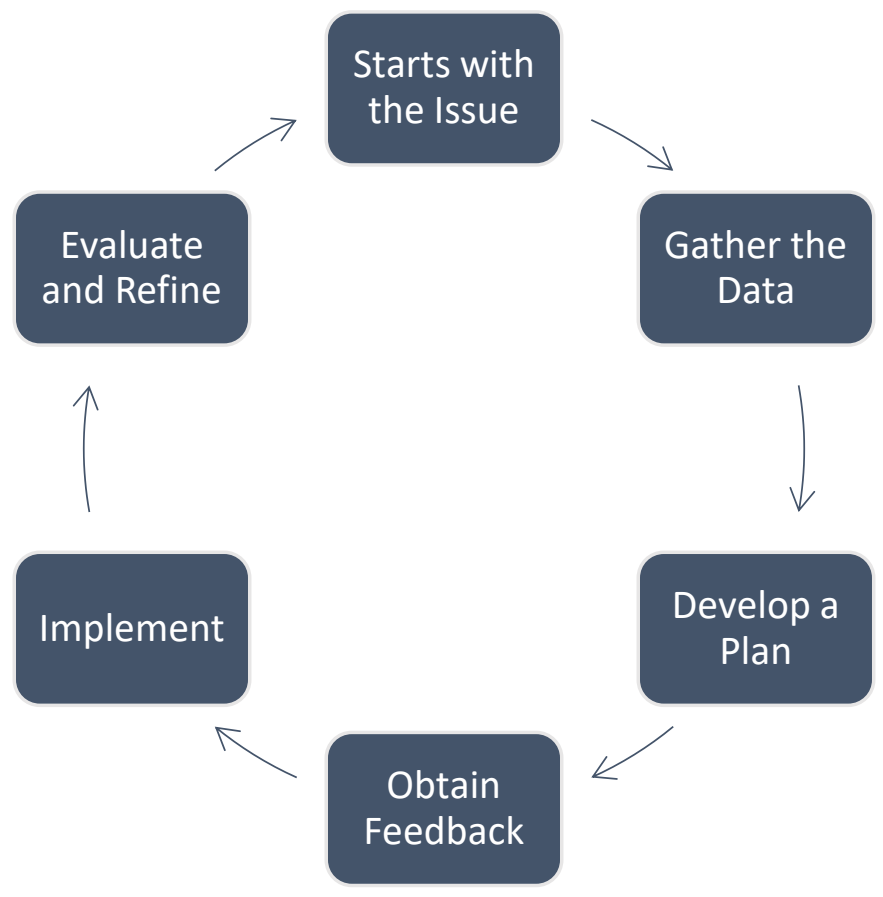

\section{Theme 8 - Creation of a Tool}

One of the best ways to ensure that the work being done by departments and offices is to establish a framework they are to follow. This framework, throughout the research, appears as a tool kit, a step-by-step guide, or a roadmap for many of the agencies to follow. The tools vary by agency, but are used in order to ensure that the entire organization is moving towards the same goal. The City of Seattle, City of Madison, City of San Antonio, and the County of Santa Clara provide a step-by-step tool kit that guides their staff during the decision-making, program/policy development process. As mentioned under the methodology section, these steps can be used to 
42 I P a g e

May 2020

Córdova | Equity-Based Resource and Service Allocation

both inform the community, and at the same time keep departments on the right path (City of

Seattle, 2019; City of Madison, 2019; City of San Antonio, 2019; County of Santa Clara, 2019).

Another item that these tools have in common is that they are heavily informed by or similar to the "Racial Equity Toolkit" created by GARE. The Racial Equity Toolkit serves as a guiding roadmap for agencies that are exploring the implementation of equity-based accountability in their government structure (Nelson and Brooks, 2016). The benefit of having such tools is that it helps with the development of clear and specific goals, makes the agency cognizant of who is being effected or impacted by the changes, and creates a method of accountability (Nelson and Brooks, 2016; City of Seattle, 2019).

The other type of tool that is created for the remaining agencies is seen as a general work plan that outlines the work that is being done by each of the departments. This narrative type work plan still includes specific action items to be done by each entity within the agency. The City of Portland Parks and Recreation Department created a list of goals that it wishes to accomplish, and within each goal is a set of strategies and action items (Hendricks, et. al., 2017). The City of Oakland and the City of Dallas takes a similar approach by grouping like topics and measures into categories that naturally fit within certain departments (City of Oakland, 2018; City of Dallas, 2019). For example, the indicators, measures, and topics that dealt with preschool enrollment, school attendance, and experience and turnover of teachers, were all categorized under the topic area of education. This categorization helps departments align with the general work plan and know what to work towards (City of Oakland, 2018). 
43 I P a g e

May 2020

Córdova | Equity-Based Resource and Service Allocation

\section{Theme 9 - Passage of Legislation to Support Equity Work}

Another common trait that these agencies have is the passage of legislation that specifically creates an initiative, department or office that allows for the equity-work to be done. In 2010, King County passed Ordinance 16948 that outlined the thirteen areas that would become their "Determinants of Equity," the plan that dictates how they will establish and further equity within their community (Beatty and Foster, 2015). This legislation is what sparked their modern-day, fully implemented work plan that is followed through all of their services, ranging from education and early childhood development to health and human services, and parks and recreation (Beatty and Foster, 2015). In 2009, the City of Seattle passed a resolution formally creating the Race and Social Justice Initiative that had already been doing work since 2004 (City of Seattle, 2011). Though the work was already being done, and the city departments and offices were working towards building a more equitable Seattle, the passage of this resolution strengthened the initiative and gave it the political backing that it needed to become more effective (City of Seattle, 2011).

While a resolution or ordinance is not necessarily needed to implement an equity-based resource allocation work plan or framework, it provides undeniable political support to be able to realize a wider impact. The City of Dallas founded their Office of Equity and Human Rights in October 2018, but it was not until May 2019 that they passed the Equity Resolution (City of Dallas, 2019). This resolution defined the disparities that existed between populations, especially those of color, and highlighted the additional steps that would be taken through training, budget development, public policymaking, and the creation of specific teams within the agency's structure (City of Dallas, 2019). The latter is an example of the next theme. 


\section{Theme 10 - Creation of an Office or Department Specific to Equity}

As mentioned in the prior theme, the creation of an Office or Department to specifically further the work plan of equity is also a theme that is seen consistently in many of the published reports that the ten agencies had. This is an important theme to note, as it assists in the centralizing and implementing of equity through the policy, programs and decision-making of a given agency and their jurisdiction (City of Seattle, 2008). Along with the centralizing of furthering the equity-based framework and work plans, creating an office also means committing resources to it in the form of staffing and a budget. This means that the agency or organization would have made a financial commitment to furthering the effects of equity, however they defined it, into programs, policies, or budgets (Beatty and Foster, 2015). The following agencies, listed in Table 3, had created an office or department solely dedicated to furthering equity:

Table 3: List of Equity Offices and/or Departments

\begin{tabular}{|l|l|}
\hline \multicolumn{1}{|c|}{ Agency } & \multicolumn{1}{|c|}{ Office/Department Name } \\
\hline City of Dallas, Texas & Office of Equity \\
\hline City of Oakland, California & Office of Race \& Equity \\
\hline City of Portland, Oregon & Office of Equity and Human Rights \\
\hline City of San Antonio, Texas & Office of Equity \\
\hline City/County of San Francisco, California & Office of Racial Equity \\
\hline City of Seattle, Washington & Office of Civil Rights \\
\hline King County, Washington & Office of Equity and Social Justice \\
\hline
\end{tabular}


Córdova | Equity-Based Resource and Service Allocation

The three entities that did not have a specific office or department dedicated to equity were the County of Santa Clara Public Health Department (California), the City of Madison (Wisconsin), and the City of Minneapolis (Minnesota). The County of Santa Clara does not have a specific office of racial equity, but the public health department incorporates equity into the budgeting, program and policy making process (Fenstersheib, Peddycord and Ferrer, 2011). The City of Madison does not have a specific office, but it adopted the Racial Equity and Social Justice Initiative, a program within the Office of Civil Rights. The City of Minneapolis does not have a dedicated office or department, but instead has the Strategic and Racial Action Plan as a program within the City Coordinator's Office (City of Minneapolis, 2019; City of Minneapolis, 2020). Though DCYF does not have a specific office within its organization, the City and County of San Francisco, the supervising jurisdiction of the department, recently adopted legislation creating the Office of Racial Equity, and appointed its first director in January 2020 (Su, 2016; Su, 2017).

\section{Theme 11 - Data: Economic Indicators}

When creating a methodology and framework guiding how the agency will implement an equity-based framework or work plan, one of the key data points that was observed multiple times was that of economic indicators. Many of the work plans in some way compiled and analyzed data on economic levels within their jurisdiction. This included looking at poverty levels and median income, for example. The City of Dallas obtained measurements on average income among populations of color and contrasted it to white populations (City of Dallas, 2019). The City of Portland also conducted the same type of research, analyzing what percentage and demographic of its population was living beneath the poverty line (Hendricks, et. al., 2017). In order to understand the population that they were trying to serve with equity, the agencies 
46 | P a g e

May 2020

Córdova | Equity-Based Resource and Service Allocation

gathered data on economic levels. This was not only to understand the population, however, it was also to measure changes that derived from their work.

This research has shown that a significant portion of the agencies have implemented measures and indicators that report out the economic health of their given jurisdiction. King County incorporated indicators regarding unemployment rates and poverty levels of its population (Beatty and Foster, 2015). The City of Seattle listed one of its initial goals in 2008 as to increase equity among its contracted vendors and within its workforce (City of Seattle, 2008). Many of the jurisdictions focused on economic indicators when developing their framework and work plans because they saw a strong correlation between socioeconomic standing and whether or not the individual was a member of the population of color (City of Oakland, 2018; City of Seattle, 2008; Beatty and Foster, 2015; City of Dallas, 2019). The City of Dallas saw marginal gains in socioeconomic standing from 2018 to 2019, but saw that a black person was still at least two times more likely to experience child poverty than a white person (City of Dallas, 2019). By obtaining raw data to build a baseline, these agencies are able to observe whether or not their policies or programs are creating an effect on the socioeconomic disparity, or whether they need to be altered.

\section{Theme 12 - Data: Neighborhood Level(s)}

The data points that demonstrate neighborhood levels varied among the agencies that included them in their frameworks or plans. While some, like the City of Dallas, included elements like access to housing or transportation, others, like King County, included elements such as residents' satisfaction with quality of life, and trust among their neighbors (City of Dallas, 2019; Beatty and Foster, 2015). The City of Oakland took the approach of trying to 
47 I P a g e

May 2020

Córdova | Equity-Based Resource and Service Allocation

analyze and understand both neighborhood and civic life in their community. The city broke out their elements into four categories: built environment, civic engagement, environmental health, and transportation and infrastructure (City of Oakland, 2018). All of these elements centered around the notion of what everyday life is like for an Oakland resident. The city incorporated measures to analyze residents' access to a car, and frequency of bus lines in given neighborhoods, pedestrian safety, conditions, and quality of parks in given neighborhoods, and the amount of trash or pollution levels in that portion of the community (City of Oakland, 2018).

DCYF measures the neighborhood levels and public life under its overarching element of safe and nurturing environments. Like King County, DCYF measures qualitative self-reported data, such as sense of safety in one's neighborhood, as well as quantitative data, such as percentage of adult probationers living in a specific neighborhood (Su, 2016). The sense of safety within one's neighborhood can be correlated to the level of success that an individual experiences in his or her life. People of Chinese descent may not feel as supported by the community if they live in a neighborhood where graffiti reading "no more Chinese" has been written on a wall (Su, 2016). In San Francisco, the Bayview-Hunters Point neighborhood was among the neighborhoods that experienced the highest level of crime between 2012-2014. This neighborhood also has the statistic of generating $17 \%$ of all referrals to the Juvenile Probation Department and $15 \%$ of all bookings to the Juvenile Hall detention facility from its residents ( $\mathrm{Su}$, 2016). As mentioned previously, DCYF also looked at data on adult probationers, $17 \%$ of whom lived in the Bayview-Hunters Point neighborhood (Su, 2016). While the strong correlation exists, a causal relationship cannot be formed. It can, however, inform public administrators within DCYF on what types of programming and resources it should allocate to this specific 
neighborhood in an effort to reduce these statistics, and the likelihood of probation referrals and incarceration.

\section{Figure 5: San Francisco Resident Response (Sense of Safety)}

\section{Low-income residents, transgender people, and residents of color}

\section{feel less safe in San Francisco than other residents.}

\section{Source: Su, 2016.}

\section{Theme 13 - Data: Criminal Justice}

This data point was commonly collected by the research as well, but like the other main data points listed, it also varied in how it was used. King County broke this data point out into two different areas when analyzing its key findings. The first area that the county analyzed was that of "Community and Public Safety" in which it observed residents' sense of safety in neighborhoods of color, in comparison to neighborhoods that were predominantly white (Beatty and Foster, 2015). The second area was that of "Law and Justice" in which the county analyzed data regarding incarceration and the likelihood of youth incarceration when looking at populations of color, lower income, and/or populations where English was not their primary or first language, and then compared it to white populations (Beatty and Foster, 2015). DCYF also made this an element in the creation of their "Service Allocation Plan." The department obtained data from local police and court jurisdictions to analyze the likelihood of youth incarceration, and weighed that against the types of services and resources allocated to the neighborhoods from which those youths primarily came (Su, 2017). 
The City of Oakland was similar to King County in this regard, as it split up its data on criminal justice among four different elements: incarceration, law enforcement, staffing, and community stressor (City of Oakland, 2018). The city's holistic view on the matter of public safety allowed it to have a well-rounded view of the criminal justice matters in their community. It allowed it to quantify the concerns they already had, and assign it a score in order to observe any correlational effects on the changes year over year. Incarceration and community stressors were among the lowest measures, out of the overall report, that the City of Oakland quantified with the scores being 1.0 and 1.7, respectively, out of a maximum total of 100 (City of Oakland, 2018). The City of Oakland's element of incarceration measured the inequitable representation of black residents experiencing felony arrests, and jail or prison incarceration, in comparison to white and Asian residents (City of Oakland, 2018). The City of Seattle also incorporated elements of criminal justice into their work plan. The city involved the Seattle Police Department and the community in town hall meetings to discuss systematic oppression, institutional racism within the community and ways to better those relationships and historical reputation (City of Seattle, 2015).

\section{Theme 14 - Data: Education Level(s)}

Education seemed to be another commonly used data point in the research. The City of Dallas used this measure to analyze the effect of early education, elementary and middle school education, high school education and adult-level education, which consisted of college level education and adults without a high school diploma (City of Dallas, 2018). 
50 | P a g e

May 2020

Córdova | Equity-Based Resource and Service Allocation

Figure 6: City of Dallas Education Indicator Success

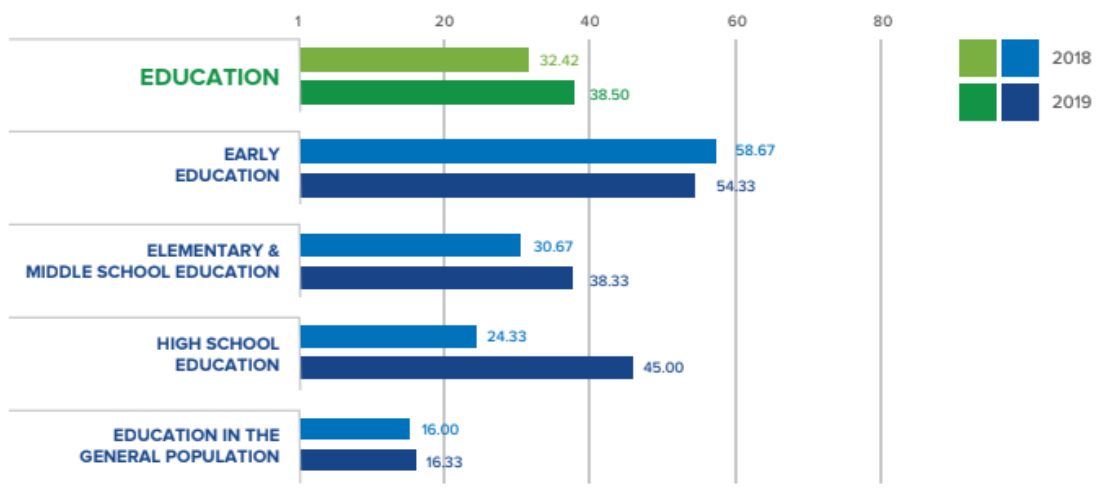

\section{Source: City of Dallas, 2019.}

While the City of Dallas used these elements and measures to obtain data on its populations, it was also able to observe year-over-year changes. While some measures had marginal or slight decreases, the city was able to observe an exponential growth in high school education. This was a notable improvement, with the main measure of high school dropouts improving its score from 40 in 2018 to 78 in 2019 (City of Dallas, 2019). The City of Oakland, a fellow CUNY-ISLG partner of Dallas, also used education as a central theme, with the elements including enrollment, achievement, program access and teachers. This report, however, painted a different picture for the City of Oakland, as it depicted two of the lower scores in the report, with suspensions and representation of student population(s) earning a 1 (City of Oakland, 2018). This does, however, allow the city to understand what areas it could focus on, and how to improve its efforts.

\section{Theme 15 - Data: Public Health}

This research project has found strong correlation between overall public health and the 
51 I P a g e

May 2020

Córdova | Equity-Based Resource and Service Allocation

demographics of a given community (Fenstersheib, Peddycord and Ferrer, 2011; City of

Oakland; Su, 2017). DCYF uses its partnership with the San Francisco Public Health Department to address this element, which they view as emotional well-being of a given area, specifically as it relates to children and youth, which is their participant population (Su, 2017). The department mixes the need for mental and emotional health services into this service area, as it states that mental health is a major factor in someone's overall health ( $\mathrm{Su}, 2017)$. These factors have informed the department in a way that has helped them create plans to help establish wellness centers and other types of overall health services in specific places to promote access, such as on a school campus ( $\mathrm{Su}, 2017)$. The City of Minneapolis echoes this sentiment, as their described goal is to promote positive youth development in order for them to avoid experiencing negative, unsafe and risky situations (City of Minneapolis, 2019).

As one would expect from a public health agency exploring and seeking racial equity, the County of Santa Clara Public Health Department also researched the divide of public health and the ethnicity/race of a given population. The public health department claims that there are significant differences in health status, and that it is more than just due to the genetic makeup of a person, but is instead strongly correlated to the socioeconomic and racial makeup of a person (Fenstersheib, Peddycord and Ferrer, 2011). The department claims that the data they have captured shows that there is a strong correlation between poor health and people living in poverty and those of color. The correlation becomes even stronger when the two latter elements are combined with someone of color also living in poverty (Fenstersheib, Peddycord and Ferrer, 2011). These findings and data points that the department has published make an argument for incorporating some level of public health data into the creation or exploration of an equity-based framework or work plan. 
52 | P a g e

May 2020

Córdova | Equity-Based Resource and Service Allocation

\section{Theme 16 - Baseline Data vs Change Data}

Research relies on data-informed practices, and data-driven decision-making. Data allows researchers to quantify information that confirms their thoughts, instincts, and narratives. The power of data is shown in many aspects of life, especially in the realm of public administration. Data like time, however, changes and manifests itself in different ways. Approximately half of the entities in this research project have clearly defined a way in which to use the element of ongoing data to measure changes over time (Su, 2016; City of Oakland, 2018; City of Seattle, 2015; Beatty and Foster, 2015; City of Dallas, 2019). The City of Dallas and City of Oakland have similar frameworks in this regard and produce annual results for their measures. The City of Dallas demonstrated the changed in their scores over the period for the two years for which it has been recording the data. (City of Dallas, 2019). The initial year of 2018 provides the agency with a baseline year of data to then compare all future results against.

The stated benefit to this method of data tracking is that it provides detailed data points over a period of years, which can allow for greater analysis and trend identification. As the City of Oakland and City of Dallas continue this work, they will be able to observe the ebbs and flows from year-to-year, and correlate specific programs, policies or changes that may have potentially had an effect on the population being studied. The other agencies in this study did not explicitly state whether or not they obtain year-over-year data, or whether they have a baseline data set from when they first developed and implemented their equity-based frameworks or work plans.

\section{Theme 17 - Retrospective History}

This theme may potentially be the hardest to manage, and on par with the involvement of race in the framework in regard to political sensitivity. The theme of retrospective history largely 
53 | P a g e

May 2020

Córdova | Equity-Based Resource and Service Allocation

deals with an agency admitting that there were previous, and maybe still existing, systematic, and institutional methods of oppression and racism within its jurisdiction (City of Oakland, 2018; Hendricks, et. al., 2015). The City of Portland started its published report by giving a brief historical overview of the city and its experiences with racism. It uses an example of John Charles Olmsted, the nephew of one of the designers of New York's Central Park, and his role in establishing a robust parks system in Portland. The report, however, pivots to how even parks in Portland were segregated by race, and that access to many of the public amenities of high quality was restricted for populations of color up until the civil rights movement (Hendricks, et. al., 2015).

The County of Santa Clara Public Health Department also states that there is a large disparity between the investment in the disadvantaged community members and their overall health levels. Although the county, as a whole, spends more per capita on people of color, a large disparity in health equity and access still exists in lower-income populations of color (Fenstersheib, Peddycord and Ferrer, 2011). By focusing the approach on the individual, as Santa Clara County does by their high per capita spending, it hinders the ability to remedy systematic racial inequities in public health as it is not able to truly address or impact issues on a broad population level. This has led the department to seek, explore, and ultimately implement racial equity into their scope of services (Fenstersheib, Peddycord and Ferrer, 2011). The City of Oakland also offered a brief history of systematic racism, including the electing of a known Ku Klux Klan member to its city council in the late 1920's, and the decay of neighborhoods and effects of the white fight and redlining between the 1940's and 1950's (City of Oakland, 2018). It is hard for an agency to know where it is going and what it needs to do if it does not understand where it is coming from, and what truth it is trying to change. 
54 | P a g e

May 2020

Córdova | Equity-Based Resource and Service Allocation

\section{Recommendations}

The City of San José has begun the exploration phases of implementing equity-based frameworks and work plans. It has held City Council meetings, Rules and Open Government Committee meetings and Study Sessions that were dedicated to the discussion of using an equity framework, mainly for their budget process (Liccardo, 2019; Peralez, et. al., 2019; Peralez, et. al., 2019; Rios and Wilcox, 2019). State level assembly members who represent the districts made up mostly by the City of San José have issued messaging supporting the movement towards building an equity-based framework (Kalra, 2019). The issue that the City of San José, however, is facing now is that it has no current framework to base its equity work on, and the exploration of developing a framework can lead in many different approaches. PRNS, however, already has some very basic levels and principles of equity in its operations. For example, the department, like many other parks and recreation departments, has a scholarship fund meant to aid residents who cannot afford the full cost of a recreational program.

The research indicates that one beneficial approach would be for PRNS to explore and develop an equity framework and work plan incorporating the following themes, as listed in Table 4. 
55 | P a g e

May 2020

Córdova | Equity-Based Resource and Service Allocation

Table 4: Themes for PRNS' Exploration

1. Community Engagement 8. Data Sourcing

2. Involvement of Race 9. Data: Economic Indicators

3. Involvement of Internal Partners 10. Data: Neighborhood Level(s)

4. Involvement of External Partners 11. Data: Criminal Justice

5. Providing Published Reports 12. Data: Education Level(s)

6. Providing a Methodology 14. Data: Public Health

7. Creation of a Tool 15. Baseline Data vs Change Data

The research project excluded the following themes: Legislation to Support Work, Creation of an Office/Department Specific to Equity Work, and a Retrospective History of San José. The main reason why these themes were excluded from the final recommendation is because of the responsibility and authority levels behind these themes. While PRNS can be a leader and champion for these themes, they are more suited for the larger City of San José government entities, such as the City Manager's Office, the Mayor's Office, and/or the City Council. Though this is the case, PRNS can benefit from initial work that the larger government entity of the City of San José has embarked on, such as the study sessions and the city's membership in the GARE Northern California network. The themes that were selected for recommendation are themes that the department could have autonomy over, and where there should be hierarchical or authority barriers. 
Córdova | Equity-Based Resource and Service Allocation

This research has analyzed the fourteen recommended themes, and sorted them into three overarching general areas as listed in Table 5.

Table 5: Overarching Themes

\begin{tabular}{|lll|}
\hline Data Sourcing Development & \\
- Data Sourcing & - Data: Criminal Justice \\
- Baseline Data vs Change Data & - Data: Education Level(s) \\
- Data: Economic Indicators & - Data: Public Health \\
- Data: Neighborhood Level(s) & - Involvement of Internal Partners \\
Feedback and Input Development & Community Engagement \\
- Involvement of Race & - Development of Reports \\
\hline Framework Development & \\
\hline & Selection of a Methodology \\
\hline
\end{tabular}

\section{Data Sourcing Development}

One of the overarching themes that was observed throughout this research is the need to obtain data, especially demographic data, to enable the governmental agency to understand the socioeconomic makeup of its community. As shown in Figure 8, the relationship between data and the equity plan is a cycle. This relationship is an ongoing one and requires an ongoing commitment from PRNS, both morally and financially, in order to observe positive results from their work. As mentioned in the findings, each of these indicators provides an insight for government agencies on 
57 | P a g e

May 2020

Córdova | Equity-Based Resource and Service Allocation

the impact of the demographics of the community. PRNS should aim to replicate many of these efforts, and identify the top data measures in each category or theme. While correlations among themes have been observed, each theme's data set provides a demonstrative narrative of its own.

\section{Figure 7: Data Sourcing Cycle}

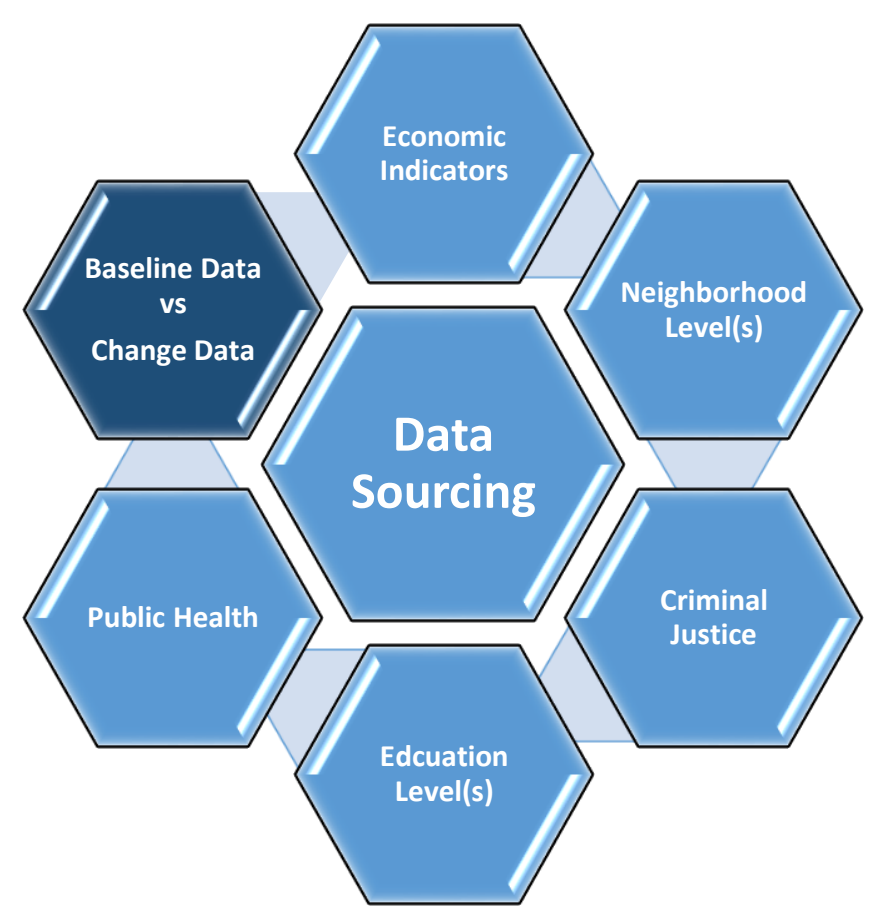

In order to ensure the accuracy of its data, it is recommended that PRNS use the United States Census Bureau, the County of Santa Clara Public Health Department, the San José Police Department, County of Santa Clara Law \& Justice section (which includes, the Juvenile Probation Department, Adult Probation Department, and Court System), and any other local, county, state, or federal government agency that can provide data on the themes above. The importance of selecting the appropriate sources is to ensure that the information is coming from a reliable, established entity that has a higher likelihood of longevity, so that the same data points can be tracked over time, from an entity using the same methodology. 
Córdova | Equity-Based Resource and Service Allocation

PRNS has the ability to improve on only data collection and analysis models by using the Geographic Information System (GIS). GIS is a platform that can be, and has been, used by the department to map their data points. In Figure 9, in partnership with PRNS, the City of San José has already developed a map, graphically demonstrating the disparity in median income in their Citywide Scholarship Dashboard (Marsh, Rios Jr. and Wilcox, 2020). This tool will provide a visual aid to the department, and ultimately stakeholders, on where the socioeconomic disparities exist, and can enable them to target certain geographic areas with resources, programs, or policies to build equity.

\section{Figure 8: 2019 Citywide Scholarship Dashboard GIS Map}

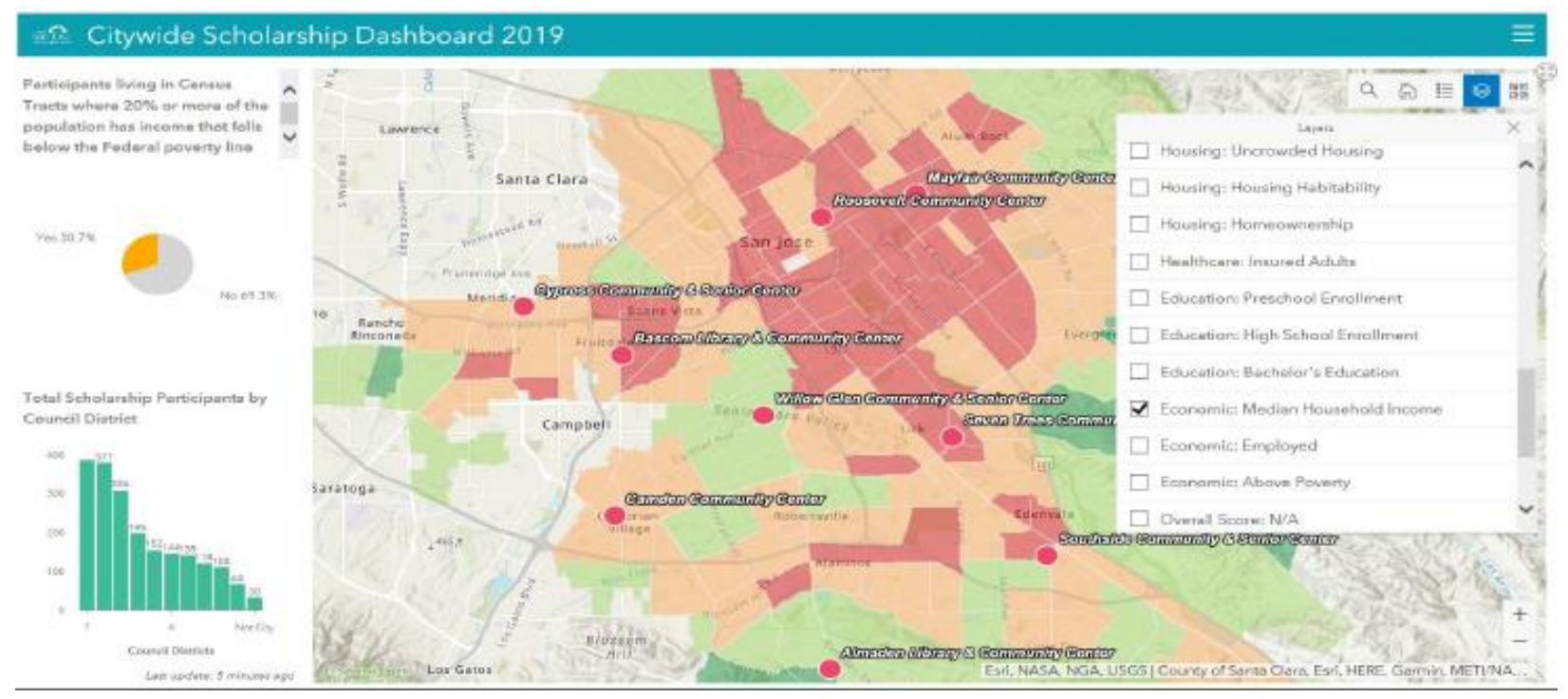

\section{Source: Marsh, Rios Jr., and Wilcox, 2020.}

The last step of data sourcing is the establishment of a baseline year of data for use in future comparisons. This shape is colored differently in Figure 8 because it can be viewed as a stand- 
59 | P a g e

May 2020

Córdova | Equity-Based Resource and Service Allocation

alone item that will be used after the first year of implementation. In succeeding years, the new data will be compared to the baseline to track progress toward equity goals based on asset allocations, while annual data allow for incremental evaluation of changes resulting for program adjustments and resource investments.

\section{Feedback and Input Development}

Another key overarching area that PRNS will need to incorporate into its equity work plan is the collection of feedback from internal and external stakeholders, the broader community, and the target neighborhoods. Ultimately, the community will be impacted by the creation of equitybased frameworks and the work plan. The City of San José, in partnership with external stakeholders and internal city departments and offices, has initiated the community engagement component by holding two public study sessions in which the topic of equity was discussed, as well as what it means to the City of San José (Andrews and Nelson, 2019; Marsh, Rios Jr. and Wilcox, 2020). Civic engagement is fundamental to the development of this plan, and can potentially lead to a citizen's advisory board when the initiative is fully implemented. Feedback and input development, however, is a multi-faceted activity.

As seen in Figure 10, PRNS must work to identify who their internal and external stakeholders are. The City of Seattle used stakeholders in their data analysis and framework development (Lally, 2017). The city used their initial research to conduct data informed conversations with the community and their stakeholders, which included community-based organizations, nonprofit leaders, and internal city staff. These conversations provided the City of Seattle with qualitative data to support the assumptions developed from the compilation of quantitative data from public agency sources (City of Seattle, 2008). One of the areas in which 
$60 \mid \mathrm{P}$ a g e

May 2020

Córdova | Equity-Based Resource and Service Allocation

assumptions were created was the topic of racial inequity within the city's jurisdiction. The engagement of stakeholders (internal, external, and community-at-large) provided the City of Seattle with data and first-hand experience on how severe the disparity and oppression is in its current form.

These types of conversations can enlighten PRNS on what root causes and factors exist within the City of San José that are creating, and in some cases furthering, the racial inequities felt by the community. In addition to simply identifying the different stakeholders, PRNS will need to develop a communication and outreach plan on how to obtain the qualitative data from these entities. This type of outreach and communication can come in the form of continued public study sessions, community town hall meetings, door-to-door canvassing, and surveying.

\section{Figure 9: Feedback and Input Development}

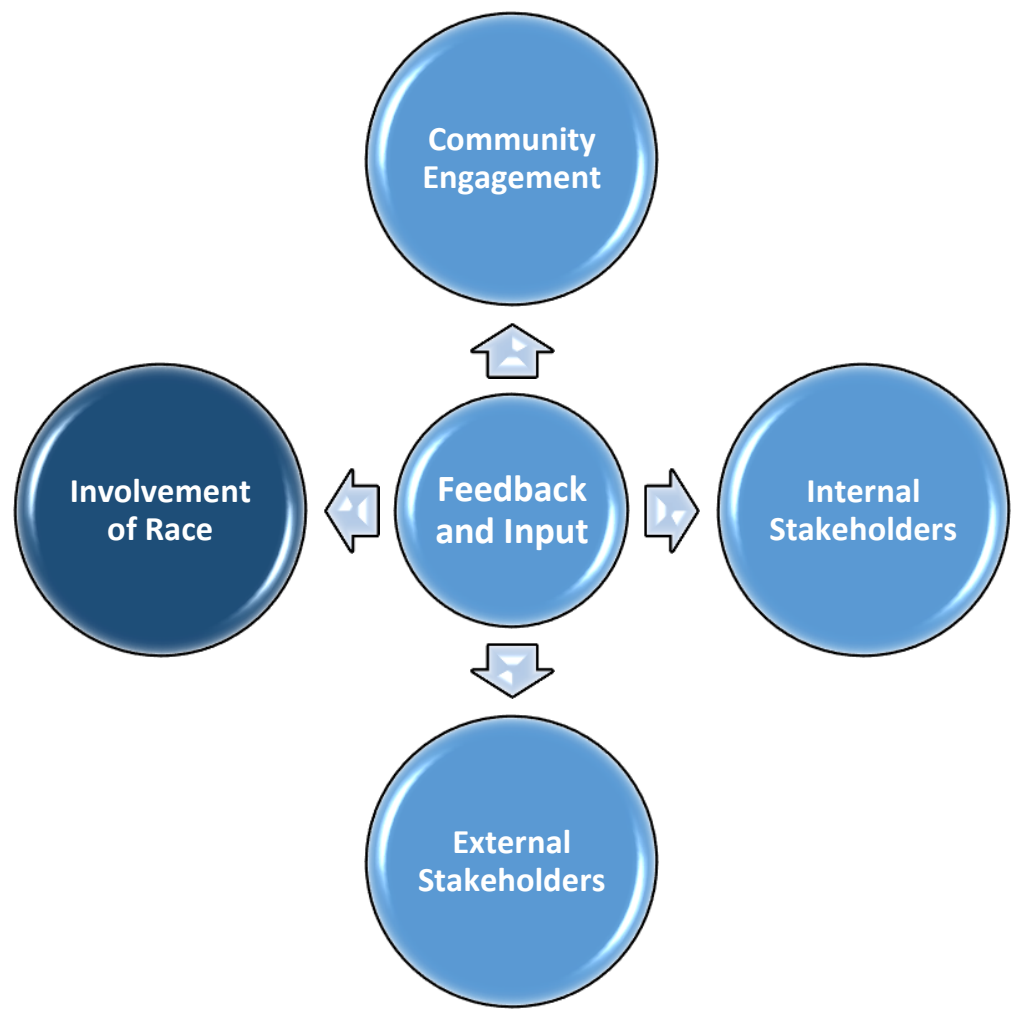


61 I P g e

May 2020

Córdova | Equity-Based Resource and Service Allocation

\section{Framework Development}

Ultimately, if PRNS decides to embark on the creation of a foundational equity work plan, the department will need to create documents that promote transparency and an informed community. In the infant stages of this development, the three main themes that will need to be addressed are the creation of a methodology, a tool, and plan to develop published annual or biennial reports as shown in Figure 11 below.

\section{Figure 10: Framework Development}

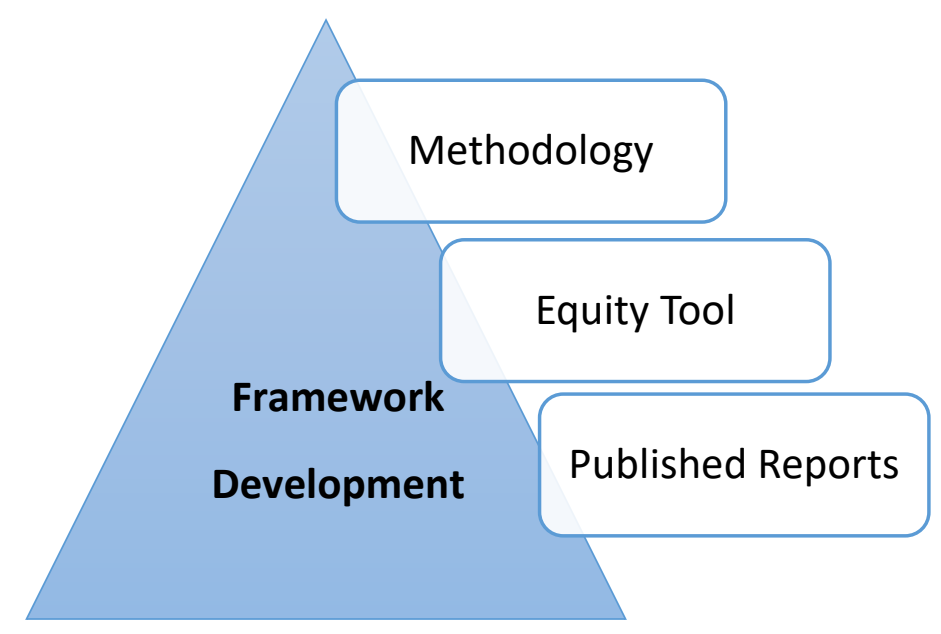

The methodology will allow all stakeholders to understand how the department aims to seek and obtain knowledge on issues of equity within the city, and sets forth a plan on how it will aim to address these issues within its programs, policies, or initiatives. The creation of a tool will ensure that all partners involved in the project are following the same set of guidelines, which helps with consistency and organizational definitions. Lastly, the department will not be able to produce a report on its findings and measures right away, as it will have to observe changes after the implementation year. PRNS, however, may wish to publish an initial report that establishes the baseline it will be using to compare its work plan and results against after the implementation year. 
62 | P a g e

May 2020

Córdova | Equity-Based Resource and Service Allocation

It is important to note that any deviations from the baseline report will need to be communicated and justified to garner community trust, reduce the risk for unmeant and unanticipated scrutiny, and promote and encourage government transparency.

The three overarching themes should be followed in the order laid out above in order to create an informed framework. By starting with Data Sourcing Development, the department will be able to have a general understanding of the general demographics of the City of San José and will be able to begin to see trends. This start will also allow for the department to have a datainformed dialogue with the community, internal and external partners, and will inform their direction on how to incorporate race into their plan. Lastly, with all of the gathered data and feedback, the department will be able to develop a written plan and framework on how it will embark on its equity-based work plan. 


\section{CONCLUSION}

The sector of equity-based resource and service allocation is a relatively newer field within public administration. Not many resources or established examples of this approach to community services exist, but many government agencies and jurisdictions are beginning to explore this strategy. The ninth largest city in the country, Dallas, Texas, is in its third full year of fully implementing its citywide equity-based work plan (City of Dallas, 2019). San José, being the tenth largest city in the county, has a chance to become one of the leaders in the sector of equity-based resource allocation. This research provides a fundamental outline and steps for PRNS to follow to become a leader within the City of San José government structure. By championing an equity work plan, and building on the developments that already exist, the department can build out an equitybased resource and service allocation plan to meet the need of its constituents. Though this research project does not provide a perfect solution to end inequity in the city, it provides a basic framework which the department can use to build a robust plan to achieve the goal of more equity in resource allocation. 


\section{SOURCES CONSULTED}

Andrews, L., Nelson, J. (2019). San José city council study session. City of San José, California: City Council Study Session.

https://sanjose.legistar.com/View.ashx?M=F\&ID=8057237\&GUID=D5D1CD73-1C9B432B-B1E5-496FB90F28B6

Arauco, V.P., Gazdar, H., Hevia-Pacheco, P., Kabeer, N., Lenhardt, A., Masood, S.Q., Naqvi, H., Nayak, N., Norton, A., Sabharwal, N.S., Scalise, E., Shepherd, A., Thapa, D., Thorat, S., Tran, D.H., Vergara-Camus, L., Woldehanna, T., Mariotti, C. (2014). Strengthening social justices to address intersecting inequalities post-2015. Overseas Development Institute. https://www.odi.org/sites/odi.org.uk/files/odi-assets/publications-opinionfiles/9213.pdf

Atkinson, A.B., Piketty, T., Saez, E. (2011). Top incomes in the long run of history. Journal of Economic Literature. 49(1). https://www-jstororg.libaccess.sjlibrary.org/stable/29779750

Azong, J.A., Wilinska, M. (2017). Into a footnote: Unpaid care work and the equality budget in Scotland. European Journal of Women's Studies. 24(3). https://doiorg.libaccess.sjlibrary.org/10.1177/1350506816643731

Baker, D.L. (2010). Revisiting user fees in challenging fiscal times. The Public Manager. 39(2). http://bi.gale.com.libaccess.sjlibrary.org/essentials/article/GALE\%7CA390091633/4ea5 $\underline{02 c 4 a e c 3175 c 5 b 10 f c 9 e a 533 a 90 e ? u=c s u s j}$ 
65 | P a g e

May 2020

Córdova | Equity-Based Resource and Service Allocation

Beatty, A., Foster, D. (2015). The determinants of equity: Identifying indicators to establish a baseline of equity in King County. King County, Washington: Office of Performance, Strategy and Budget. https://www.kingcounty.gov/ /media/elected/executive/equitysocial-justice/2015/The_Determinants_of_Equity_Report.ashx

Beaulieu, E.D. (2001). An equitable allocation model: Designing an equitable budget allocation model in an institution of higher learning. ProQuest Information and Learning. University of New Brunswick, Canada. http://search.proquest.com.libaccess.sjlibrary.org/docview/305445608?accountid=10361

Belgarde, D., Crowder, K., Danielson, B., Hayden, P., Martinez, M., Maykovich, X., Ornelas, I., Saldaña, R., Ramos, M., Romich, J., Stolz, R. (2016). RSJI community survey. City of Seattle Office for Civil Rights: Race \& Social Justice Initiative. https://www.seattle.gov/Documents/Departments/CivilRights/2016\%20RSJI\%20Commu nity\%20Survey.pdf

Bernabei, E. (2017). Racial equity: Getting to results. Local and Regional Government Alliance on Race and Equity. https://www.racialequityalliance.org/wpcontent/uploads/2017/09/GARE_GettingtoEquity_July2017_PUBLISH.pdf

Chakraborty, K., Blackburn, V.C. (2013). Efficiency and equity in funding for government schools in Australia. Australian Economic Papers. 52(3-4). https://doiorg.libaccess.sjlibrary.org/10.1111/1467-8454.12012 
$66 \mid \mathrm{P}$ a g e

May 2020

Córdova | Equity-Based Resource and Service Allocation

City of Dallas. (2019). Dallas equity indicators: Measuring change toward greater equity in

Dallas. City of Dallas, Texas. https://dallascityhall.com/departments/office-ofequity/DCH\%20Documents/equality-indicators-booklet-2019.pdf

City of Madison. (2019). Racial equity and social justice tool: Process guide. City of Madison, Wisconsin: Racial Equity \& Social Justice Initiative. https://www.cityofmadison.com/civil-rights/documents/RESJIprocessguide.pdf

City of Minneapolis. (2019). Strategic \& racial equity action plan 2019-2022. City of Minneapolis, Minnesota.

http://www.minneapolismn.gov/coordinator/Equity/sreap/WCMSP-222843

City of Minneapolis. (2020). Strategic \& racial equity action plan update: Reporting period plan adoption-Q4 2019. City of Minneapolis, Minnesota. Committee of the Whole-Race Equity Subcommittee. http://www.minneapolismn.gov/coordinator/Equity/sreap/WCMSP$\underline{222842}$

City of Oakland (2018). Oakland equity indicators: Measuring change toward greater equity in Oakland. City of Oakland, California: Department of Race and Equity. https://cao94612.s3.amazonaws.com/documents/2018-Equity-Indicators-Full-Report.pdf

City of San Antonio. (2019). Fiscal year 2020 budget equity tool. City of San Antonio, Texas: Office of Equity. https://www.sanantonio.gov/Portals/0/Files/Equity/BudgetEquityTool.pdf

City of San Antonio. (2019). Equity atlas: Online equity maps. City of San Antonio, Texas: Office of Equity. 
67 | P a g e

May 2020

Córdova | Equity-Based Resource and Service Allocation

https://cosagis.maps.arcgis.com/apps/MapSeries/index.html?appid=9cdb2a0222ff4b4fb8 $\underline{1 \mathrm{~b} 1452 \mathrm{fd} 9 \mathrm{~d} 15 \mathrm{fa}}$

City of San José. (2014). Living wage policy. City of San José, California: City Council Policy. https://www.sanjoseca.gov/home/showdocument?id=20059

City of Seattle. (2011). Race and social justice initiative: Accomplishments 2009-2011. City of Seattle, Washington: Race \& Social Justice Initiative. https://www.seattle.gov/Documents/Departments/RSJI/RSJIAccomplishments20092011.pdf

City of Seattle. (2015). Race and social justice initiative: Vision \& strategy 2015-2017. City of Seattle, Washington: Race \& Social Justice Initiative. https://www.seattle.gov/Documents/Departments/RSJI/rsji-2015-2017-plan.pdf

City of Seattle. (2019). Racial equity toolkit to assess policies, initiatives, programs, and budget issues. City of Seattle, Washington: Race \& Social Justice Initiative. https://www.seattle.gov/Documents/Departments/RSJI/RacialEquityToolkit_FINAL_Au gust2012.pdf

City of Seattle. (2008). Report 2008: Looking back, moving forward. City of Seattle, Washington: Race \& Social Justice Initiative. https://www.seattle.gov/Documents/Departments/RSJI/Jan20FINALRSJIrept.pdf

County of Santa Clara. (2019). Racial and health equity: Budget equity assessment tool FY 2019. County of Santa Clara, California: Public Health Department. 
68 | P a g e

May 2020

Córdova | Equity-Based Resource and Service Allocation

County of Santa Clara (2019). County of Santa Clara Public Health Department: Strategic plan 2019-2022. County of Santa Clara, California: Public Health Department. https://www.sccgov.org/sites/phd/about/Documents/sccphd-strategic-plan-2019-2022.pdf

Cox, J. (2019, March 13). Workers at the lower end of the pay scale finally are getting the most benefit from rising wages. $C N B C$. Retrieved from https://www.cnbc.com/2019/03/13/workers-at-lower-end-of-pay-scale-getting-mostbenefit-from-rising-wages.html

Curren, R., Nelson, J., Marsh, D.M., Noor, S., Lui, N. (2016). Racial equity action plans: A how to manual. Haas Institute for a Fair and Inclusive Society. University of California, Berkeley. https://www.racialequityalliance.org/wp-content/uploads/2016/11/GARE$\underline{\text { Racial-Equity-Action-Plans.pdf }}$

Cummings, V. (2019). Oakland race and equity baseline indicators report: An overview of existing conditions for east and west Oakland compared to the City of Oakland to inform the Howard Terminal Community Benefits Program. City of Oakland, California. https://cao-94612.s3.amazonaws.com/documents/FINAL_Baseline-Report.pdf

Fenstersheib, M., Peddycord, D., Ferrer, F.J. (2011). Health and social inequity in Santa Clara County. Santa Clara County Public Health Department. https://www.sccgov.org/sites/phd/hi/hd/Documents/ship-report.pdf

GIZ. (2018). Equity Budgeting Tool. Eschborn, Germany: GIZ. https://www.genderingermandevelopment.net/custom/images/contentBilderGalerie/bilder Galerie1000501/GIZ-Equity-budgeting-tool-2018-EN.pdf 
69 | P a g e

May 2020

Córdova | Equity-Based Resource and Service Allocation

Hendricks, A., Lee, C., Guillén-Chapman, K., Horner, B., Cairo, J., Yocom, J., Hallquist, J., Kennedy-Wong, E., Rodriguez, M., Smith, J., Evans, M., Lam, T. (2017). Five-year racial equity plan: Furthering citywide racial equity goals and strategies. City of Portland, Oregon: Portland Parks \& Recreation. https://www.portlandoregon.gov/parks/article/623289

Kalra, A. (2019). RE: June 10, 2019 special meeting for the budget final public hearing, and June 11, 2019 item 3.3 - Mayor's June budget message for fiscal year 2019-2020. City of San José, California: City Council. http://sanjose.legistar.com/gateway.aspx?M=F\&ID=f2c5cf6f-3e9f-4da1-a8a21394daeac22c.pdf

Lally, P. (2017). 2016 Race and social justice initiative annual report. City of Seattle Office for Civil Rights: Race \& Social Justice Initiative. https://www.seattle.gov/Documents/Departments/RSJI/2016\%20RSJI\%20Annual\%20Re port $\% 20$ Spread.pdf

Liccardo, S. (2019) June budget message for fiscal year 2019-2020. City of San José City Council. https://www.sanjoseca.gov/home/showdocument?id=48431

Liscow, Z.D. (2017). The efficiency of equity in local government finance. New York University Law Review. 92(6). 1828-1908.

Lustig, N. (2011). Commitment to equity assessment (CEQ): A diagnostic framework to assess governments' fiscal policies handbook. Society for the Study of Economic Inequality. 212. http://ideas.repec.org/p/inq/inqwps/ecineq2011-212.html 
70 | P a g e

May 2020

Córdova | Equity-Based Resource and Service Allocation

Maguire, A. (2017) Figure 1: Things I found in... Su, M. (2017). Final services allocation plan.

San Francisco, California: Department of Children, Youth, and Their Families.

https://static1.squarespace.com/static/5c01d13ab98a788a7a0cfd93/t/5c995f1b104 c7b647468cc03/1553555238040/Final+SAP.pdf

Marsh, D.S., Rios Jr, A., Wilcox, L. (2020). Equity study session: Achieving equity in San Jose. City of San Jose, California: City Council Study Session. https://sanjose.legistar.com/View.ashx?M=F\&ID=8057237\&GUID=D5D1CD73-1C9B432B-B1E5-496FB90F28B6

Mattoo, A., Subramanian, A. (2012). Equity in climate change: An analytical review. World Development. 40(6). https://doi.org/10.1016/j.worlddev.2011.11.007

Nelson, J., Brooks, L. (2016). Racial equity toolkit: An opportunity to operationalize equity. Local Government on Race and Equity. https://racialequityalliance.org/wpcontent/uploads/2015/10/GARE-Racial_Equity_Toolkit.pdf

Peralez, R., Jimenez, S., Carrasco, M., Esparza, M., Arenas, S. (2019). June budget message for fiscal year 2019-2020. City of San José, California: City Council. http://sanjose.legistar.com/gateway.aspx?M=F\&ID=6dca6443-d5ce-4217-a482f9d04e868892.pdf

Peralez, R., Jimenez, S., Carrasco, M., Esparza, M., Arenas, S. (2019). Equity study session. City of San José, California: Rules and Open Government Committee. https://sanjose.legistar.com/View.ashx?M=F\&ID=7672359\&GUID=2403D261-F3FC4B78-8B36-DEC4AFFB51ED 
71 | P a g e

May 2020

Córdova | Equity-Based Resource and Service Allocation

Rios Jr., A., Wilcox, L. (2019). Equity study sessions. City of San José, California: Rules and Open Government Committee.

http://sanjose.legistar.com/gateway.aspx?M=F\&ID=745d7741-d20e-4187-8ccad29f45469ae8.pdf

Robert Wood Johnson Foundation. (2017). Figure 2: Things I found in... City of Dallas. (2019). Dallas equity indicators: Measuring change toward greater equity in Dallas. City of Dallas, Texas. https://dallascityhall.com/departments/office-ofequity/DCH\%20Documents/equality-indicators-booklet-2019.pdf

Rodriguez-Bolivar, M.P., Galera, A.N., Muñoz, L.A., Lopez-Subirés, M.D. (2014). Factors influencing local government financial sustainability: An empirical study. Lex Localis Journal of Local Self Government. 12(1). https://doiorg.libaccess.sjlibrary.org/10.4335/12.1.31-54(2014)

Riccucci, N.M. (2009). The pursuit of social equity in the federal government: A road less traveled? Public Administration Review. 69(3). https://www-jstororg.libaccess.sjlibrary.org/stable/27697878

Rosenbloom, D.H., Kravchuk, R.S. and Clerkin, R.M. (2014). Public Administration: Understanding Management, Politics and Law in the Public Sector, 8th edition, Boston: McGraw Hill

Ruckert, A., Labonté, R. (2012). The global financial crisis and health equity: Toward a conceptual framework. Critical Public Health. 22(3). https://www-tandfonlinecom.libaccess.sjlibrary.org/doi/abs/10.1080/09581596.2012.685053 
72 | P a g e

May 2020

Córdova | Equity-Based Resource and Service Allocation

Su, C. (2017). Beyond inclusion: Critical race theory and participatory budgeting. New Political Science. 39(1). https://doi-org.libaccess.sjlibrary.org/10.1080/07393148.2017.1278858

Su, M. (2016). 2016 community needs assessment: A snapshot of San Francisco's children and families. San Francisco, California: Department of Children, Youth, and their Families. https://static1.squarespace.com/static/5c01d13ab98a788a7a0cfd93/t/5c995eb441920240c $\underline{\text { 8c6ed5f/1553555133027/DCYF+CNA+final+23+Aug.pdf }}$

Su, M. (2017). Final services allocation plan. San Francisco, California: Department of Children, Youth, and Their Families. https://static1.squarespace.com/static/5c01d13ab98a788a7a0cfd93/t/5c995f1b104c7b647 $\underline{468 \mathrm{cc} 03 / 1553555238040 / \text { Final+SAP.pdf }}$

Sykes, D. (2019). 2019-2020 Adopted Operating Budget. City of San José, California: Office of the City Manager's Budget Office. https://www.sanjoseca.gov/home/showdocument?id=45411

Turan, H., Senturk, A. (2015). Local government budgeting for gender equality. Procedia Economics and Finance. 38. https://doi.org/10.1016/S2212-5671(16)30194-0

Weisman, S.R., Helmy, A., Vayong, M., Aoki, J.R. (2018) Changing hearts, minds, and structures: Advancing equity and health equity in state government policies, operations, and practices in Minnesota and other states. Mitchell Hamline Law Review. 44(4). https://open.mitchellhamline.edu/mhlr/vol44/iss $4 / 4$ 
73 | P a g e

May 2020

Córdova | Equity-Based Resource and Service Allocation

Wheeler, T., Dessou, K. (2018) Budget equity assessment tool. City of Portland, Oregion: Office of Equity and Human Rights.

https://www.portlandoregon.gov/transportation/article/556892

Zolfaghari, M.R., Peyghaleh, E. (2015). Implementation of equity in resource allocation for regional earthquake risk mitigation using two-stage stochastic programming. Society for Risk Analysis. (35)3. 434-458. 